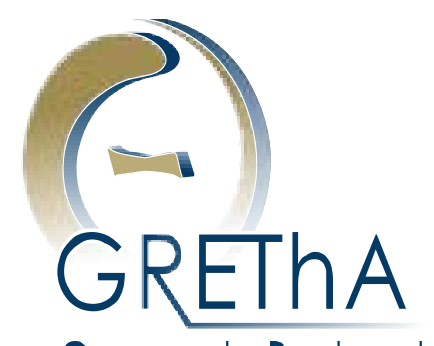

Groupe de Recherche en

Économie Théorique et Appliquée

French Textile Specialisation in Long Run Perspective (18361938) : Trade Policy as Industrial Policy

\title{
Stéphane BECUWE
}

GREThA, CNRS, UMR 5113

Université de Bordeaux

sbecuwe@u-bordeaux.fr

\&

Bertrand BLANCHETON

GREThA, CNRS, UMR 5113

Université de Bordeaux

Bertrand.blancheton@u-bordeaux.fr

Cahiers du GREThA

$n^{\circ}$ 2016-17

juin

\section{G RETHA UMR C NRS 5113}

Université de Bordeaux

Avenue Léon Duguit - 33608 PESSAC - FRANCE

Tel : +33 (0)5.56.84.25.75 - Fax : +33 (0)5.56.84.86.47 - www.gretha.fr 


\title{
French Textile Specialisation in Long Run Perspective (1836-1938) : Trade Policy as Industrial Policy
}

\begin{abstract}
By using a new database covering French international trade between 1836 and 1938 this paper focuses on the country's specialisation in textiles. It demonstrates, for the first time, the major influence of trade policy on French international trade in textiles during the first globalisation. Tariffs appear to be crucial determinants of specialisation measured by the Lafay Index. Tariffs are also major determinants of intra-industry trade in textiles. By analysing changes in tariffs between raw textiles and finished textiles and decorrelation between tariffs we show that an effective trade protection approach was applied by successive French governments in order to sustain the industrial competitiveness of textiles. Trade policy slowed down textile de-specialisation until WWI.
\end{abstract}

Keywords: textile, effective protection, specialisation, international trade, France

La Spécialisation Française dans le Textile, une Approche de Long Terme (1836-1938) : La Politique Commerciale comme Politique Industrielle

\section{Résumé}

En utilisant une nouvelle base de données couvrant le commerce international français entre 1836 1938, cet article se concentre sur la spécialisation du pays dans le textile. II manifeste, pour la première fois, l'influence majeure de la politique commerciale sur le commerce international des textiles français pendant la première mondialisation. Les tarifs douaniers semblent être les déterminants cruciaux de la spécialisation mesurée par l'indice de Lafay. Les tarifs sont aussi les déterminants majeurs du commerce intra-branche dans le textile. En analysant les changements de tarifs entre les produits textiles de base et les produits finis et la dé-corrélation entre ces tarifs, nous montrons qu'une approche en termes de protection effective a été appliquée avec efficacité par les gouvernements français successifs afin de supporter la compétitivité de l'industrie textile. La politique commerciale a ralenti la déspécialisation de l'industrie textile jusqu'à la Première Guerre Mondiale.

Mots clés : textile, protection effective, spécialisation, commerce international, France

JEL : F6, N23, N73

Reference to this paper: BECUWE Stéphane, BLANCHETON Bertrand (2016) French Textile Specialisation in Long Run Perspective (1836-1938) : Trade Policy as Industrial Policy), Cahiers du GREThA, ${ }^{\circ} 2016-17$.

http://ideas.repec.org/p/grt/wpegrt/2016-17.html. 


\section{.1. Introduction}

The textile industry appears to be a paradigmatic sector through which to study international competition during the first wave of globalisation (Betran and Huberman, 2016) and, more particularly, the reaction of earlier starters when faced with new competitors during this period. The debate surrounding the "Lancashire failure" would now appear to be over. Contemporary studies from the UK focus on how, despite the challenges of low wage competition, the British cotton industry continued to develop into the $20^{\text {th }}$ century. In line with Marshall's view, one answer is agglomeration. Lancashire captured the benefits induced by external economies of scale. Its competitive edge came from a combination of a deep pool of skilled labour as well as energy, satellite industries, bankers, insurance agents... (Broadberry and Marrison 2002, Balderston 2010, Craft and Wolf 2013).

For France the crucial question is the same: how could its long-established textile industry continue to prosper in the first part of the $20^{\text {th }}$ century when faced with the same new competitors (Italy, Japan...)? There is a large body of literature on the development of the textile industry in France but it fails to offer a complete, clear vision of the long-term role of textiles in French international trade. The contributions of quantitative economic history are very fragmented because of the lack of a complete dataset (see Weiller 1971, Bairoch 1993). Since Fohlen (1956), narrative literature has focused on the consequences of some exogenous shocks at the industry scale (silkworm diseases, cotton famine, war...) and highlights the fact that the industry declined, despite technological changes and efforts towards adaptation. Recently, French business history has studied the regional dimension of textile development: silk in the Lyon area, woollen fabrics in the North (Roubaix, Tourcoing...) and Champagne... It analyses the organisation and development of firms, aspects of agglomeration, management decisions and export strategies, but there is no macroeconomic vision.

In contrast to the UK - which chose a free trade policy between the end of 1840 s and the Great Depression - successive French governments used trade policy to promote different economic sectors and to preserve political and social stability (Todd 2008, Dormois 2009). Literature on the economic consequences of French trade policy is fragmented, focused on the short term (Cadier, 1988; Broder, 1993) or included in the tariff growth paradox debate at a global level (Bairoch 1993).

Focusing on textiles, it is crucial to study the consequences of commercial policy on the development of the industry. Did trade policy influence specialisations in the long-term? Can trade policy be considered to have been an industrial policy during the first globalisation?

Corden shows the importance of vertical relationships among products. A tariff on an input reduces the added value of the final product. Effective protection can be defined as a trade policy strategy that aims to increase the competitiveness of national companies by reducing tariffs on primary products and maintaining higher protection on finished products. Corden (1971) explores the general equilibrium implications of tariffs. 
In order to analyse the influence of trade policy on textiles, our strategy has been to build an original, disaggregated database covering the period between 1836 and 1938. Our main data source is the Tableau Général du commerce de la France avec ses colonies étrangères. We document the proportion of textiles in French international trade, we compute conventional specialisation indices and we try to analyse the influence of commercial policy on the sector with respect to effective protection during the first globalisation by using tariffs at the disaggregated level. Cliometrics provide a new view of the history of the textile industry and its international integration.

The article is structured as follows. Section 2 presents a survey of French international textile trade between 1836 and 1938. Section 3 introduces the original database and some key data. Section 4 uses conventional methodologies to analyse the dynamics of France's comparative advantage and specialisation in textiles. Section 5 focuses on intra-industry trade development in textiles considering the Linder hypothesis and the impact of tariffs. The final section discusses the relationship between trade policy and the degree of specialisation by introducing the effective protection approach. We conclude with some explanations and propose some new lines of research.

\section{.2. Survey: business history achievements and limits}

\section{A major sector in the French economy}

Textiles played a key role in French industrialisation (Markovitch 1966, Rioux 1971, Caron 1981, Crouzet 2003 ...) and appear at the heart of its integration into international relations during the $19^{\text {th }}$ century (Levy-Leboyer and Bourguignon 1990, Verley 1997). According to Markovitch the contribution of textiles to industrial added value (raw textile industry and clothing \& fabric industries) was $41.9 \%$ in $1835-44$. It then decreased to $31.4 \%$ in $1905-1913$ and $22.4 \%$ in $1934-38$.

Figure 1: Contribution of textiles to industrial added value between 1835 and 1938

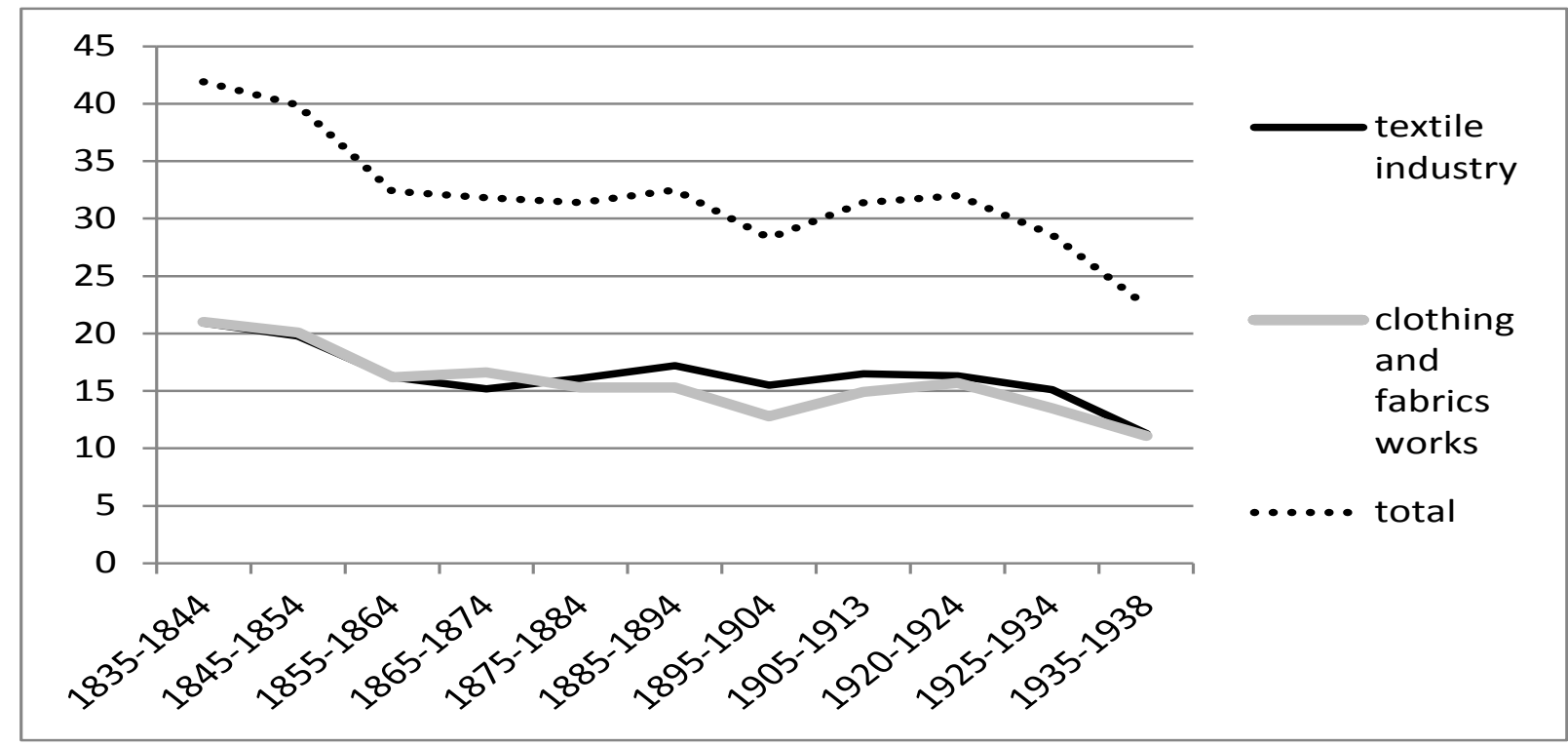

Source: Markovitch T, Le produit physique de l'économie française, Cahiers de l'ISEA, série AF, $n^{\circ} 4$, tableau 4-a, 1965. 
Verley (1997) gives a picture of French textile exports based on annual data between 1827 and 1880. Woollen, cotton and silk fabrics were the major contributors to French foreign trade. Dormois (2009), who studied the impact of protectionism in four industrialized countries (Germany, France, Italy and the United Kingdom), has calculated revealed comparative advantage indices for France in 1873, 1885, 1900 and 1913. These confirm that France specialised in finished textiles and clothes.

Historical studies highlight the great heterogeneity of the industry, the importance of the substitutability of fibres (cotton for linen and wool, a mixture of fibres after World War I) and the effects of fashion on products. Technological developments, costs and the shortage of raw materials caused each sector to develop differently. The disease that affected sericulture in the 1850s hindered the expansion of the silk industry. Although the "cotton famine" of 1861-1865 was not total because certain ships succeed in running the blockade in the United States, other cotton suppliers, for example Egypt (Fock An Chuen 1997) and India, increased in importance. The famine also offered a one-off opportunity to cotton's competitors. In the long term, however, cotton developed much more than other textiles: "in the $19^{\text {th }}$ and $20^{\text {th }}$ centuries cotton largely replaced other textiles, particularly linen. In 150 years of development, the French cotton industry increased its production a hundredfold whereas the wool trade only multiplied its production tenfold and the silk industry barely tripled in size; the linen industry actually reduced in size by about half" (Markovitch 1966: pp 19-20).

Very early on, historians regarded long-term analysis of developments in the diversity and global nature of the textile industry as a kind of challenge. Claude Fohlen (1956) who studied the textile industry in France at the peak of its development during the "Second Empire" highlights the protean nature of the textile industry, the singularity of the development pathways of its various sectors, the territorial dimension of its expansion and its decline. Moreover he excludes the silk sector from his study, considering it to be more of a luxury goods industry. Immediately, the sectorial and territorial dimensions prove to be crucial to an understanding of the industry's organisation, sectorial logic, export networks, and competitiveness...

According to Verley (1997) French industrialists specialized in high-quality textile fabrics which complemented the mass-produced British ranges that were based on technological advances (more highly-developed mechanisation). In the middle of the $19^{\text {th }}$ century France exported to a great number of markets, some of them distant (United States, Argentina and Brazil) with a premium clientele. French producers' good brand image, allied with French taste, allowed them to set fashions that were copied by their competitors in the Zollverein and Switzerland. It is worth noting that the quality positioning of French textile exports was based on reputation and testimonies relating to managerial strategy. From this point of view the Universal Exhibition of 1851 acted as a showcase for French textile know-how, the quality of which was praised, in particular with respect to silk (see Leon 1974). In a recent paper, using a new disaggregated dataset of Spanish textile imports, Betran and Huberman (2016) establish that between 1898 and 1912, unit values of imports from France were higher than those from other major countries (except Germany in the 1900s).

Business history studies textile companies' strategies of internationalisation at the same time as analysing their size, their networks within the different textile-producing regions and the 
entrepreneurial culture of their managers. Major studies include Chassagne (2012) on Veuve Guérin et fils, silk manufacturers and bankers between 1716 and 1932, Reynaud (1991) on the ribbon industry in the Saint-Etienne region 1895/1975, the works of Gayot (1998) on sheet manufacture in Sedan, those of Cazals (1983) on Mazamet and Chassagne's book (1991) on the cotton industry magnates.

Company monographs describe the development pathways of companies confronted with the opportunities and the international constraints of their time, and more rarely with arbitrations between exports and foreign direct investment. But they do not enable a global analysis of French competitiveness with respect to trade policies and transaction costs. For this, the sector level would appear to be much more relevant since it groups the issues in terms of company size, level of productivity and quality/price positioning.

\section{The heterogeneity of the textile industry}

The cotton industry developed slowly in France from the beginning of the $18^{\text {th }}$ century (first cotton factory identified in Rouen, with Delarue in 1701, then the installation of Oberkampf in Jouyen-Josas in 1754). At the end of the $18^{\text {th }}$ century the industry appeared to have concentrated on nothing more than the production of handkerchiefs, particularly in Rouen and Montpellier. The cotton industry really developed from the "Restoration" period, but it was shaken by crises (in 1836 in link with high prices practiced by the United States, in 1861-65 in relation to the American civil war). The Franco-Prussian war of 1870 led to the loss of Alsace and Lorraine which deprived France of dynamic cotton-manufacturing centres such as Mulhouse. At the end of the period the renewal of internal demand and colonial outlets (which accounted for just under $20 \%$ of national production) provided a boost to the French cotton industry. According to Albert Aftalion (1904) cotton is a more flexible plant than linen and lends itself better to manual work; in machines cotton leaves less waste while cotton thread is less fragile on mechanical looms.

The silk trade was very well developed in the Lyon region, which exported about $80 \%$ of its production. The silk industry was very much orientated towards distant markets (Great Britain and the United States but also China from the end of the 1840s, India - Charles Payen started a silkspinning business in India in 1845 - and Japan under the Meiji era). Until the middle of the $19^{\text {th }}$ century half of the raw material came from the Cévennes, the other half from Piedmont and from Asia. In France, on the eve of the Revolution, the production of cocoons was estimated at 6,200 tons a year. By the decade $1845-54$ it had reached 18,500 tons a year. Until the middle of the $19^{\text {th }}$ century the spinning industry supplied nearly half of the raw material required for weaving. In the $1850 \mathrm{~s}$ several diseases (Pébrine, Flacherie and Muscardine) affected the silkworm farms in the Cévennes, leading to an increase in the importation of raw silk from Asia. In the silk trade fashions followed one another, inspired by designers and engineers from Lyon: oriental inspiration under the "July Monarchy" and the appetite for liturgical silk. Under the Second Empire the fashion was for neoGothic and closely-woven silk fabrics.

The wool trade, also very much orientated towards export, went through many major changes in the $19^{\text {th }}$ century. Jean-Claude Daumas (2004) analyses the expansion of "the carded wool period" 
which, at its peak in the 1850s, made the fortune of Elbeuf and Sedan, then "the brushed wool period" which benefitted Fourmies, Roubaix, and Tourcoing until 1880-1890. Wool was also very widespread in Champagne, in the Ardennes (see Gayot, 1998), in Normandy and also in Mazamet for "fellmongering" (separation of the wool from the hide), in spite of an unfavourable geographical situation (Cazals, 1983). This regional dispersion appears to have been a handicap in terms of achieving external economies of scale.

For Verley the great depression of the 1870s was associated with a wholesale decline of the French textile industry. The drastic fall in the number of people with high incomes in overseas markets explains the reduction in demand for French products. At that time the liberalisation of trade and, more generally, the reduction in transaction costs increased international competition. Countries new to the textile industry started developing active export strategies... The silk trade was severely affected in the 1880 s.

At the end of the $19^{\text {th }}$ century a contrast may be seen in the fortunes of silk and wool as described by Klein (2005) and Daumas (2004) respectively. Klein describes an agglomeration effect, showing how the silk traders and financiers in Lyon developed integrated strategies in Asia, from the creation of deposit banks to the structuring of transport and communication networks between Lyon and Shanghai, thus protecting their competitiveness with respect to the British. The silk trade was also modernized: flexible silk, mechanical looms, partial dyeing. Daumas highlights the difficulties of the wool trade from the 1880s onwards: French wool exports fell by practically half between 1880 and 1913 while German and British exports increased. According to Daumas, this fall was due to failures in the commercial organisation of exports (weakness of French intelligence, the absence of financial infrastructure on the ground), unsuitable production tools (old factories, the old-fashioned nature of the mixture between spinning and weaving activities), failing corporate strategies, very little effort to adapt to demand, very little cooperation between industrialists in either Elbeuf or Sedan.

In the years after the First World War the silk industry succeeded in maintaining its dynamism thanks to its link with Parisian haute couture and the development of ready-to-wear clothing. It demonstrated its adaptability through the employment of synthetic material and mixed thread (silk, wool and cotton). The process for manufacturing artificial silk was discovered by Chardonnet at the end of the $19^{\text {th }}$ century. According to Markovitch the price of the new raw material was 15 francs per kilo between 1905 and 1913 against 35 for pure silk.

Textile exports benefitted from the undervaluation of the franc until the Poincare stabilisation. The reduction in world demand, the rise of protectionism and the end of "monetary doping" are associated with a profound crisis in the French textile industry, in particular cotton and wool.

The articles dedicated to this key sector of French foreign trade seem to be fragmentary and scattered. This literature does not offer an overview of developments in the various French textile specialisations. It focuses on the consequences on the industry of certain exogenous shocks. Business History highlights the organisation of the textile industry and its dispersed regional development. It analyses the development pathways of individual firms and their export strategies. Such history does 
not enable an analysis of the influence of commercial policy on the industry with respect to effective protection or discrimination against partners. Quantitative economic history could enable us to shed new light on the history of the textile industry and its international integration.

\section{.3. Data and overview of textiles in French trade}

\section{Data source}

To analyse changes in the composition of the textile trade in terms of both imported and exported commodities, our strategy has consisted of building an original, disaggregated database for France's foreign trade recorded annually between 1836 and 1938. Our main data source is the Tableau général du commerce de la France avec ses colonies et les puissances étrangères (Tableau général du commerce et de la navigation after 1896). We take into account 15 headings for textile imports and about 15 for exports. We classify items into three groups: primary textiles, including cotton, linen \& hemp, raw wool, raw silk; semi-finished, including cotton \& wool thread, linen \& hemp thread, silk thread; finished textiles which includes articles of clothing / lingerie, cotton fabric, jute fabric, woollen fabric, linen and hemp fabric, silk fabric.

Our definition of trade takes into account "commerce spécial (special trade)" and not "commerce general (general trade)". Data from "special trade" includes the value of goods really imported for national consumption and the value of national production exported ("special trade" excludes goods in transit). These data do not include trade from tourism which can be significant, for example for garments, underwear and silk fabrics. Another common dilemma of $19^{\text {th }}$ century trade statistics concerns the use of official prices. After 1847 the French Table only shows "annualised values" using standard prices defined by a committee ${ }^{1}$ and not "official values" based on traders' statements.

\section{Key data and overview}

Figures 2 and 3 show the importance of textiles in French foreign trade in the middle of the $19^{\text {th }}$ century. Finished textile products account for around $50 \%$ of the value of global exports in the 1830 s and the 1840 s with a large concentration of silk, woollen and cotton fabrics. During this period, France appears to have espoused a concentrated trade model, exporting a small number of products in large quantities. In international trade France appears as an "advanced" country which exports manufactured products and imports primary products. This is fully in line with the international division of labour of the period. Primary products for the textile industry account for more than $25 \%$ of imports during the same period. Verley (1997) states that France's specialisation in textiles was established by the 1820s. The textile industry played a key role in French commercial power: until 1871 France was the world's second largest exporter (see Bairoch 1993).

\footnotetext{
${ }^{1}$ In 1848 a "Commission des valeurs en douane (Customs Value Commission)" was created (for more details see Dormois (2009) chapter 4)
} 
The proportion of finished textiles in global exports decreases from the start of the 1860s until 1875 , influenced by trade liberalisation and the loss of Alsace, particularly the textile potential of Mulhouse (see Dedinger 2012). Thereafter it decreases more slowly until WWI (18\% in 1913). At the same time the proportion of primary textile exports increases rapidly in the 1860s and remains stable until WWI at around 10\%. Export of semi-finished goods was not significant before 1914 . The decline in textile exports seems to be correlated with the decline in French commercial power - especially its export capacity - in the last third of the $19^{\text {th }}$ Century, which is a well-established historical fact (see Cameron 1961, Weiller 1971, Levey-Leboyer and Bourguignon 1990, Bairoch 1993, Asselain and Blancheton 2005, Broder 2006...). Becuwe et al (2015) establish a correlation between the concentration of French exports and the balance of trade.

Figure 4 gives details of changes in exports of finished textiles. The changes in different products seem to be incompletely correlated with the historical view. At the start, silk fabric was France's top specialisation (more than 20\% of global export values in the 1850s) but the decrease in the percentage of silk fabric is very rapid from $20 \%$ in 1860 to about $14 \%$ in 1863 and only $7 \%$ in 1879. It then remains stable until WWI. In the 1920s Silk fabric remained the top French specialisation. The percentage of woollen fabric is remarkably stable at around $10 \%$ between the 1840s and the 1890s but then decreases rapidly until 1913 (only 3\%). Cotton fabric exports are very large in the 1830 s and in the early 1840 s but the percentage decreases from $15 \%$ in 1845 to $3 \%$ in 1860 (before the cotton "famine" during the American civil war). After that date it increases regularly during the first globalisation and the 1920s. In the 1930s it is the biggest category of finished textile export. Linen and hemp fabrics accounted for $5 \%$ in 1836, decreased in the 1840 s and became insignificant in the 1850s.

The percentage of garments and underwear remained stable at around $3 \%$ until the 1900 s, increased until the middle of the 1920s (up to 7\% between 1922 and 1924) before decreasing quickly to only $1 \%$ in 1938.

Figure 2: Percentage of textiles in exports between 1836 and 1938

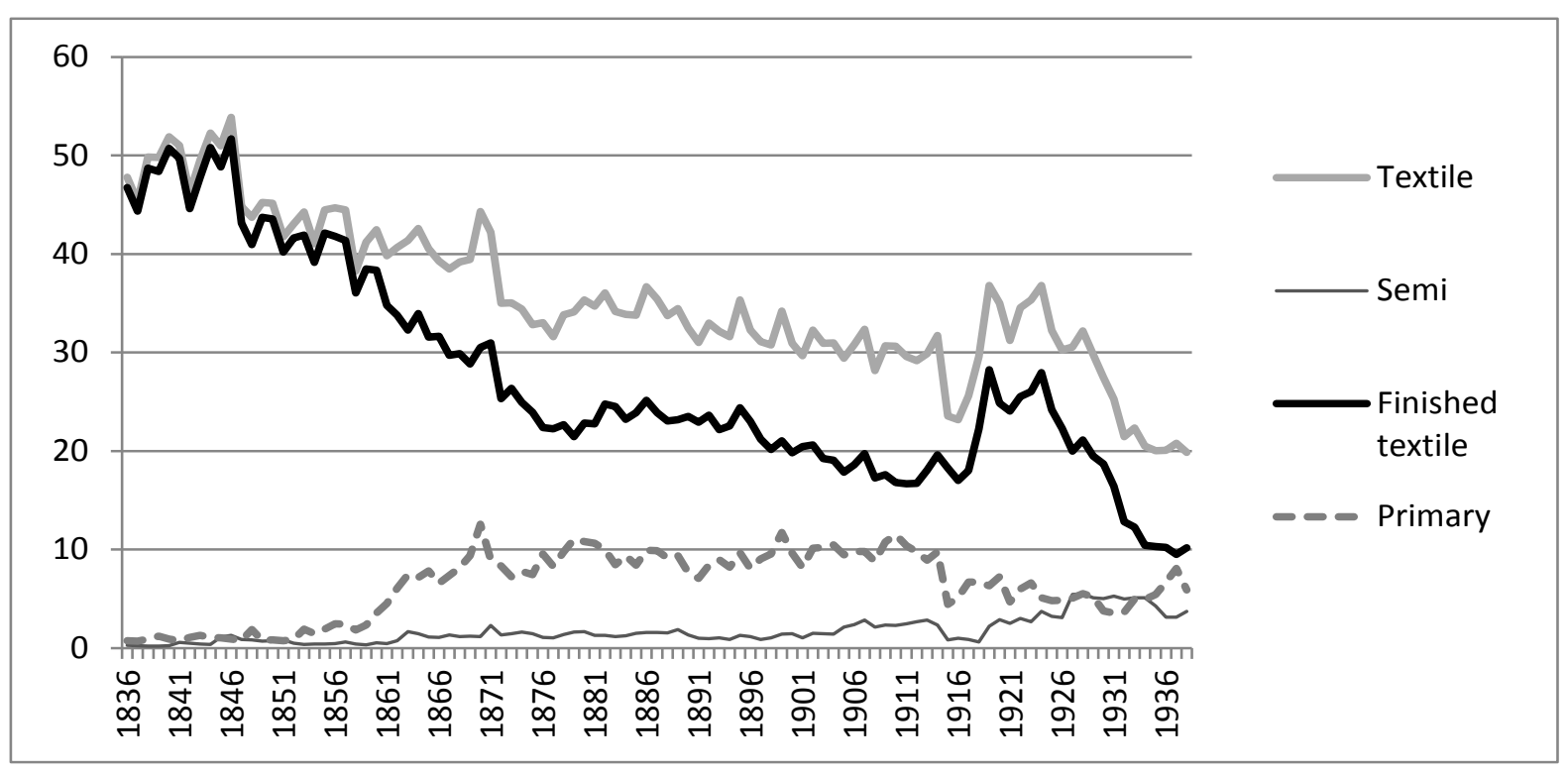


Source: Tableau général du commerce de la France avec ses colonies et les puissances étrangères (1836-1896); Tableau général du commerce et de la navigation (1897-1938); own calculations. "Primary" includes cotton, linen \& hemp, raw wool, raw silk. "Semi-finished" includes cotton \& wool thread, linen \& hemp thread, silk thread. "Finished" includes articles of clothing / lingerie, cotton fabric, jute fabric, woollen fabric, linen and hemp fabric, silk fabric

As far as imports are concerned, the percentage of textiles (essentially primary) increases until 1865 (42\%) and appears to be correlated with industrial activity. It follows economic cycles during the Second Empire, drops to $25 \%$ during the long stagnation, and stays stable until WWI (for details of cycles, see Aimar et al, 2016). France imported wool - particularly from Spain and Argentina, and cotton from the US, Egypt and India. Concentration Ratio 4 imports include primary products for the textile industry (cotton and silk are in the top 4 between 1836 and 1873 and between 1836 and 1889 respectively). The percentage of textiles increases during the 1920 s to reach $22.5 \%$ in 1928 , falls to $10 \%$ in 1931 , then goes back up to $13 \%$ in 1938 .

Figure 3: Percentage of textiles in imports between 1836 and 1938

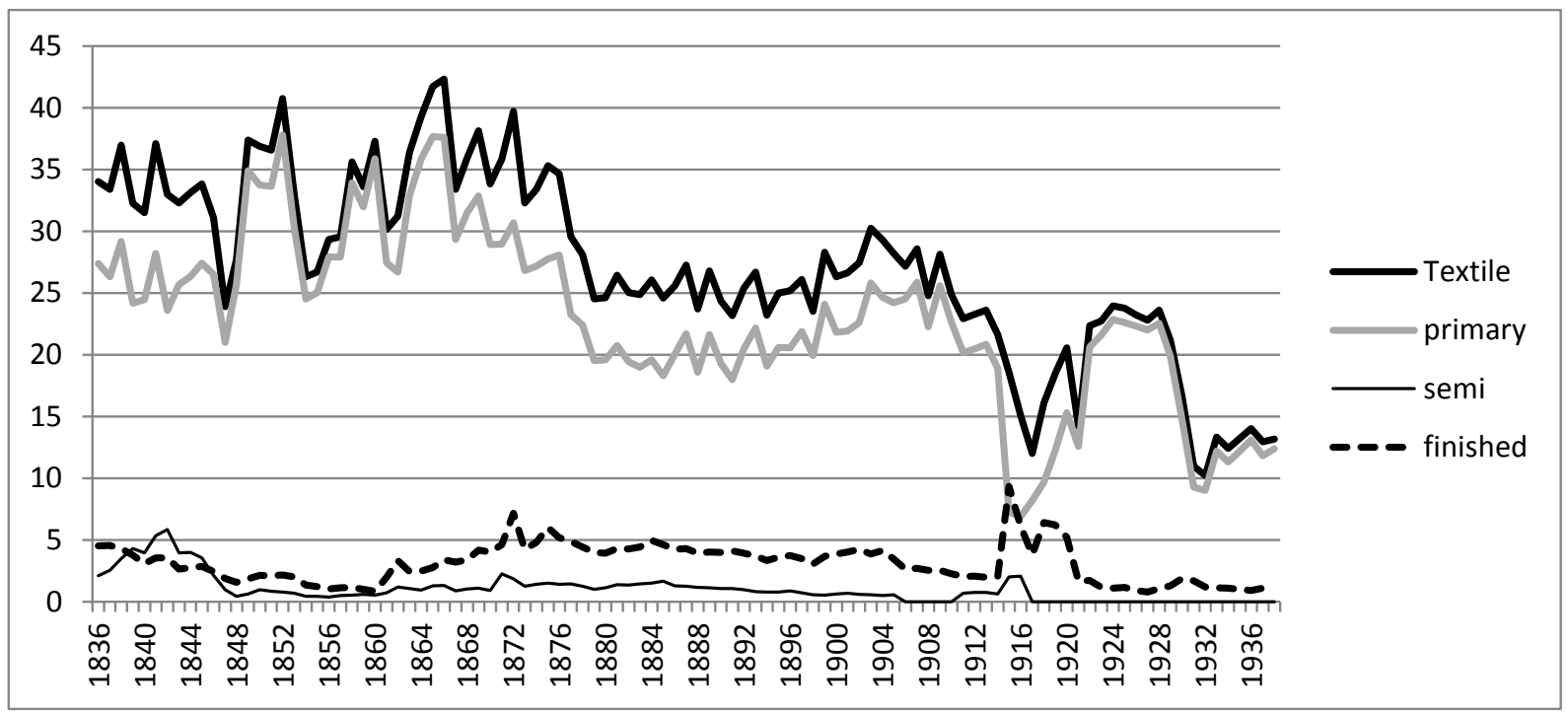

Source: Tableau général du commerce de la France avec ses colonies et les puissances étrangères (1836-1896); Tableau général du commerce et de la navigation (1897-1938); own calculations. "Primary" items include cotton, woollen scraps, linen \& hemp, wool, silk. "Semifinished" items include cotton \& wool thread, linen \& hemp thread, silk thread. "Finished" items include articles of clothing / lingerie, cotton fabric, jute fabric, woollen fabric, linen and hemp fabric, silk fabric. 
Figure 4: changes in the percentage of finished textile exports in total export value between 1836 and 1938.

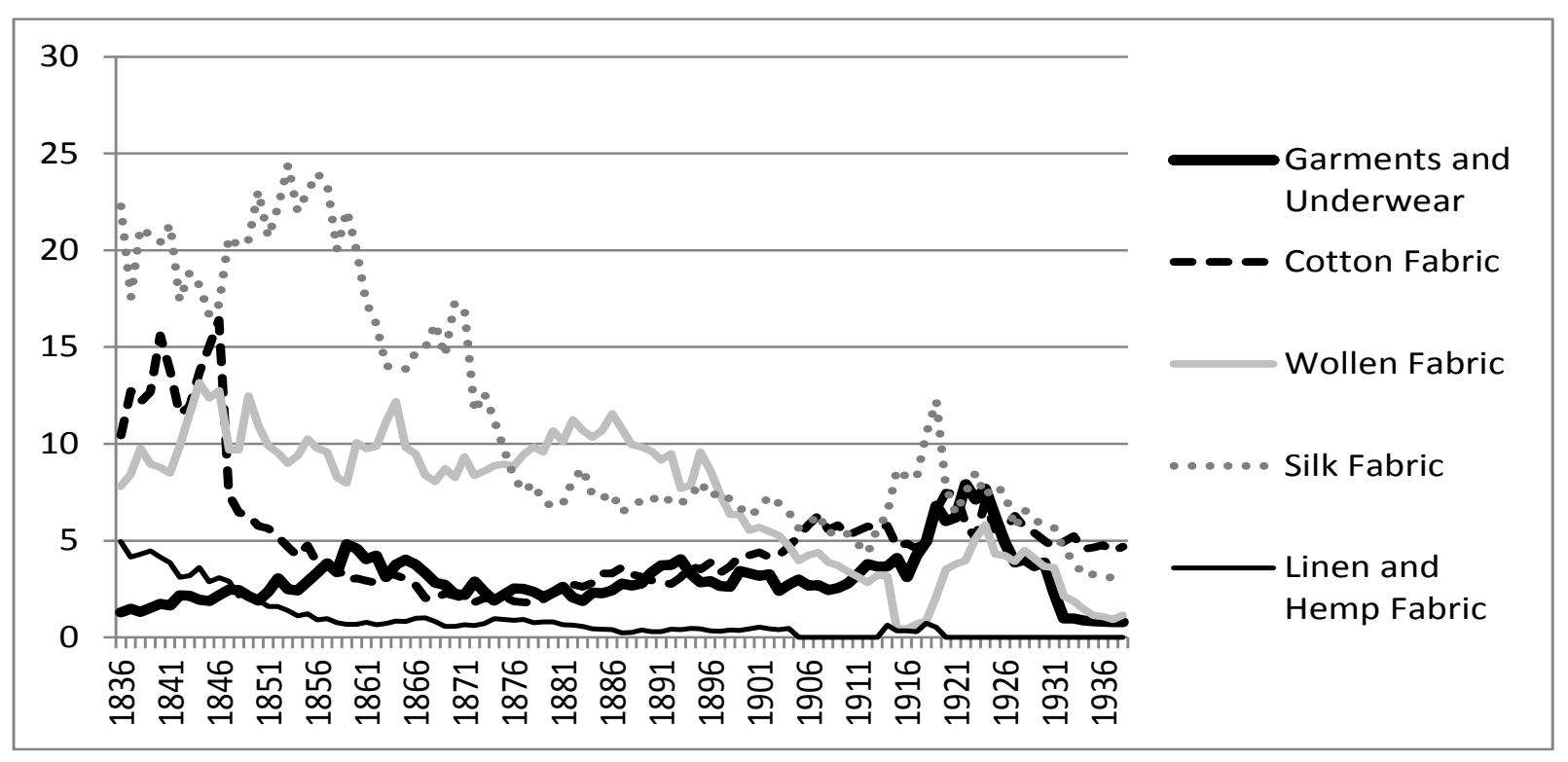

Figure 5: Changes in the percentage of primary textile imports in total import value between 1836 and 1938.

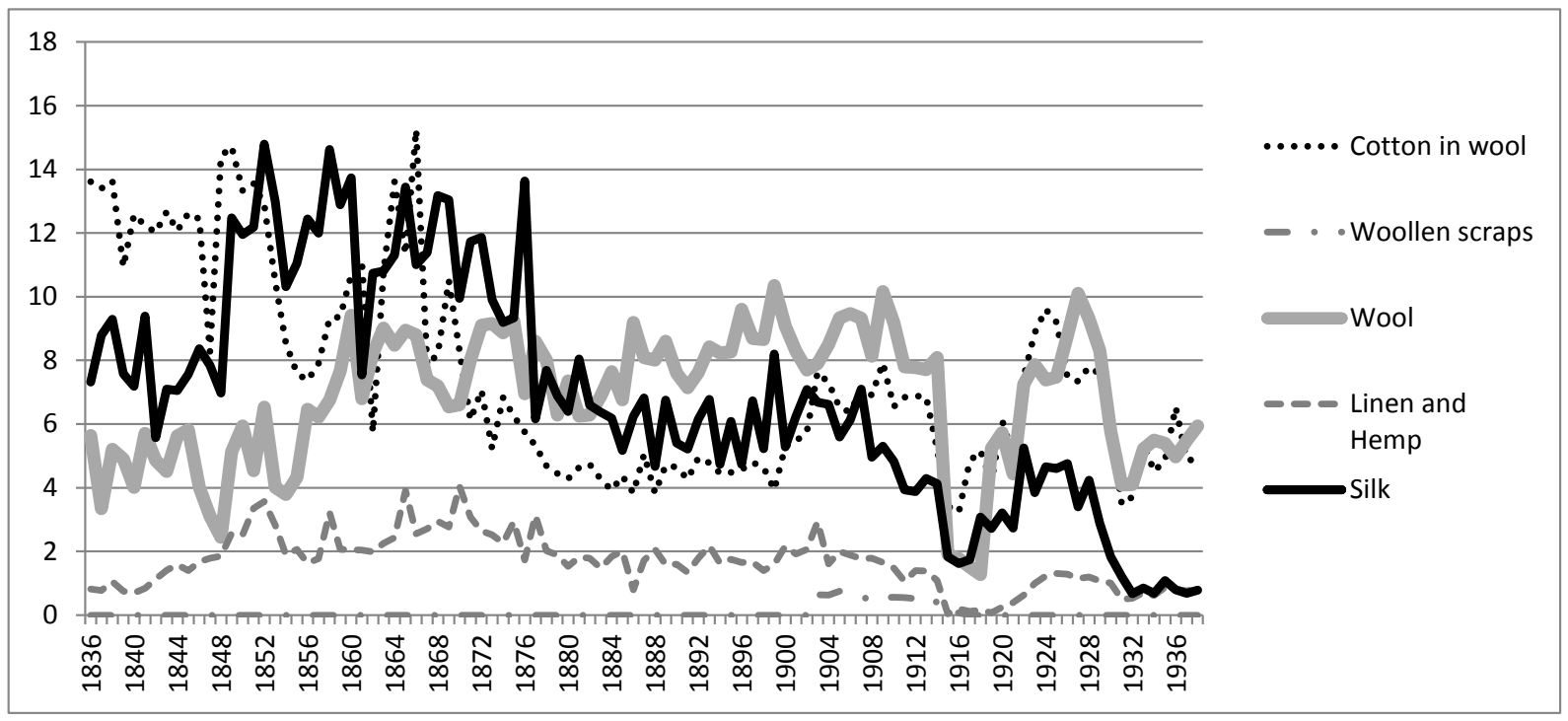


Before 1860, cotton, woollen and silk textiles and garments accounted for a large proportion of exports. Faced with increasing international competition this proportion declined during the first globalisation. This sector was once heavily criticized for the small size of its establishments and for being much less technologically progressive than its British counterpart. Subsequent research has shown that relative factor prices may help explain some of these differences (Allen, 2009). At the same time newly industrialised countries developed specialisations in textiles (Japan, Italy...). But in the long run textiles continued to play a key role in French international trade. Silk fabrics were France's top export product in the 1830s: this was still the case in the 1920s. This appears to be curious for a long-established industrial country.

\section{.4. Trade Policy and Comparative Advantage of Textiles}

In order to highlight the impact of trade policy on international trade in French textiles we select different conventional indices and apply different methodologies.

\section{Lafay Index of Specialisation}

International economics has developed many ways of measuring comparative advantage and specialisation since Balassa (1965)'s pioneering Index of Revealed Comparative Advantage. The choice of the right index depends on many factors. We have chosen to use the Lafay Index of International Specialisation (1992) which offers some advantages for historical studies. It requires only national trade statistics and in effect suitably disaggregated data for world exports are not available for our period. The Lafay Index controls for distortions from an overall net deficit. In the context of increasing intra-industry trade during the first globalisation a careful assessment of international comparative advantages requires exports and imports to be taken into consideration. By taking imports into account, the Lafay Index allows intra-industry trade and re-exporting flows to be controlled for. The Lafay Index measures the contribution of different products to changes in total comparative advantage.

We compute the Lafay Index of international specialisation for 15 items. For any given product $i$ the Lafay Index (LFI) is defined as:

$$
L F I i=100 \times\left\{\left(\frac{x i-m i}{x i+m i}\right)-\frac{\sum_{i=1}^{N}(x i-m i)}{\sum_{i=1}^{N}(x i+m i)}\right\} \times \frac{x i+m i}{\sum_{i=1}^{N}(x i+m i)}
$$

Where $\mathrm{xi}$ and $\mathrm{mi}$ are the export and import values for product $\mathrm{I}$ and $\mathrm{N}$ is the number of products.

Thus, a positive value indicates the existence of a comparative advantage in a given item (a specialisation in the $i^{\text {th }}$ good). On the contrary, negative values point to de-specialisation. All indices add up to zero, with a maximum range from 200 to -200 in the extreme case of complete specialisation of both exports and imports in one single good with balanced trade.

We have computed LFI year by year for each textile product. Lafay Indices for primary products show a permanent de-specialisation. Figure 6 shows this to be very large at the start of the period, 
until the 1870s, and smaller but significant afterwards except during WWI. For semi-finished goods a de-specialisation only in linen and hemp thread appears between 1836 and 1847 and a specialisation in cotton and wool thread during the interwar period.

Figure 6: Lafay Index of specialisation for primary textiles

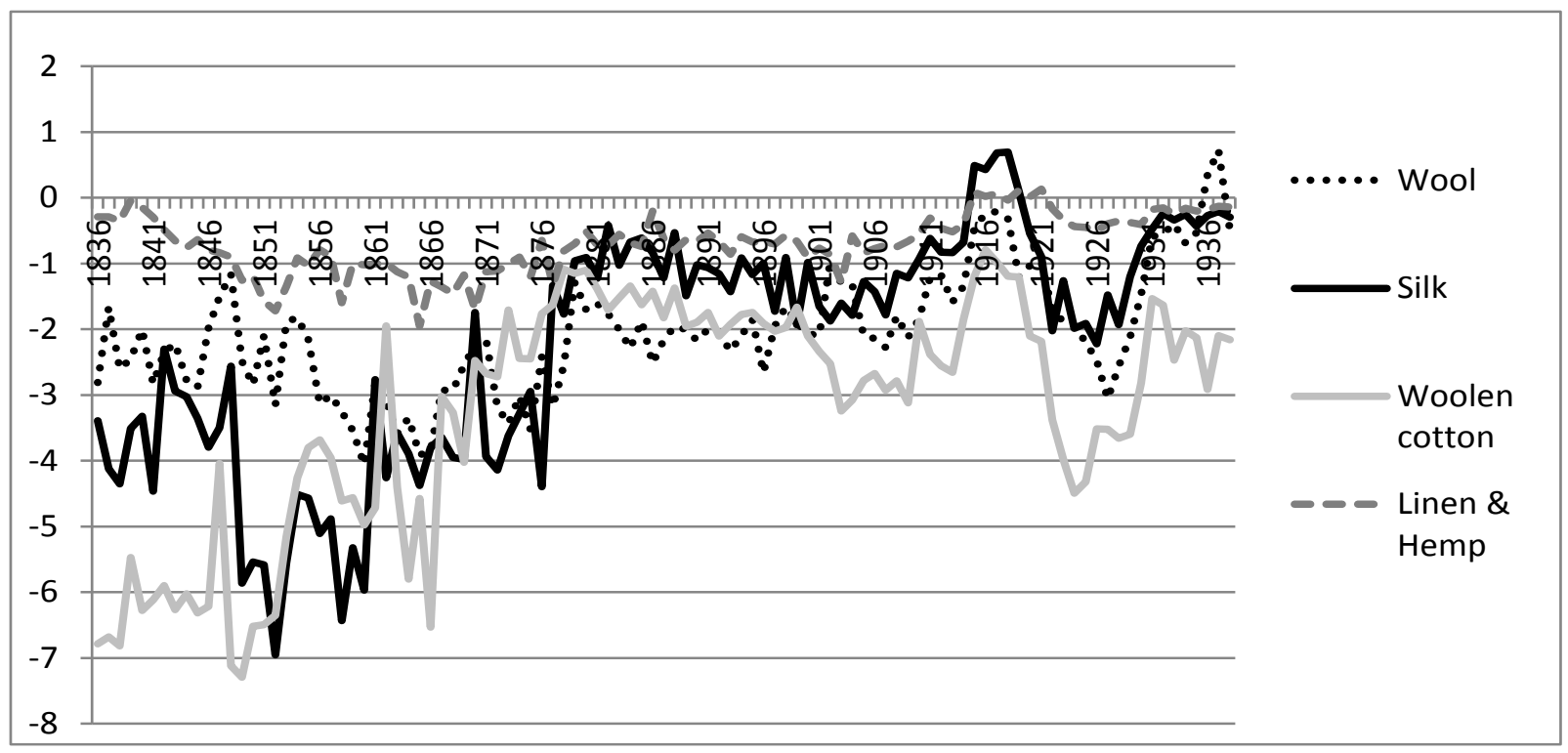

Source: Tableau général du commerce de la France avec ses colonies et les puissances étrangères (1836-1896); Tableau général du commerce et de la navigation (1897-1938); own calculations.

Figure 7: Lafay Index of specialisation for semi-finished textiles

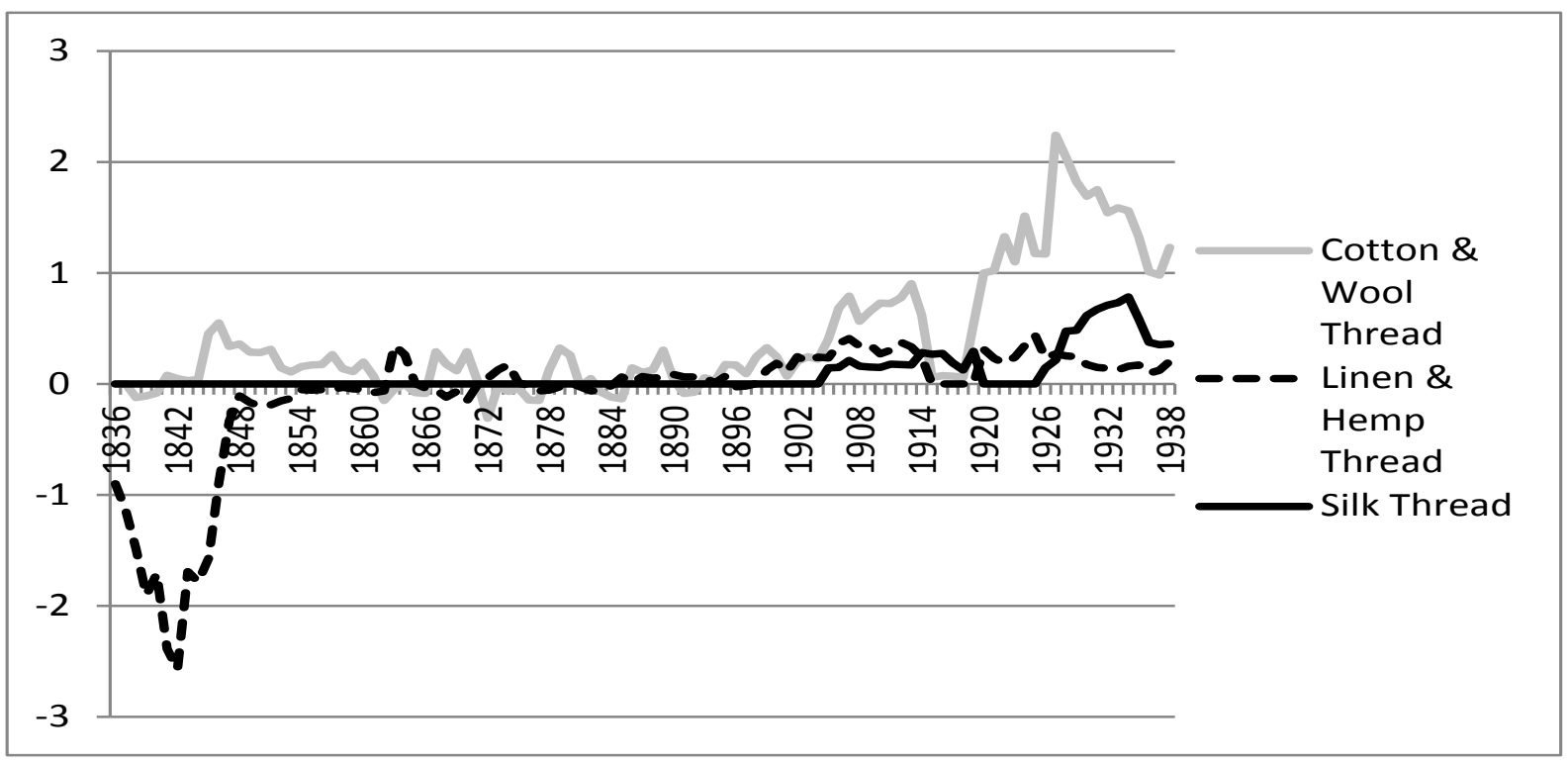


Source: Tableau général du commerce de la France avec ses colonies et les puissances étrangères (1836-1896); Tableau général du commerce et de la navigation (1897-1938); own calculations.

At the start of the period France was very highly specialized in finished textiles (silk, woollen and cotton fabrics). For silk fabrics the LFI index reached more than 10 in the 1850s, but although it decreased from the start of the 1860s, France clearly maintained a specialisation in silk until WWII based on its reputation for quality ${ }^{2}$. The LFI index was high for cotton fabric (with a peak at 8 in 1846), but it decreased sharply at the end of the 1840s and became negative in 1872 after the secession of Alsace and Lorraine to Germany. It rose from the 1880s to WWI and remained stable with a value of 2 during the interwar period. For woollen fabric, the LFI index showed greater resistance between the 1860s and the 1890s: a decrease really appeared in the 1890s and continued until the end of the period, when France lost this specialisation.

Figure 8 shows another significant specialisation in garments and underwear between 1836 and 1913 (a value of around 2), then it increased after WW1 with a peak at 4 in 1922 when it became one of France's biggest specialisations linked to the expansion of haute couture (Poiret, Patou, Chanel... ). It decreased during the great depression.

Figure 8: Lafay Index of specialisation for finished textiles

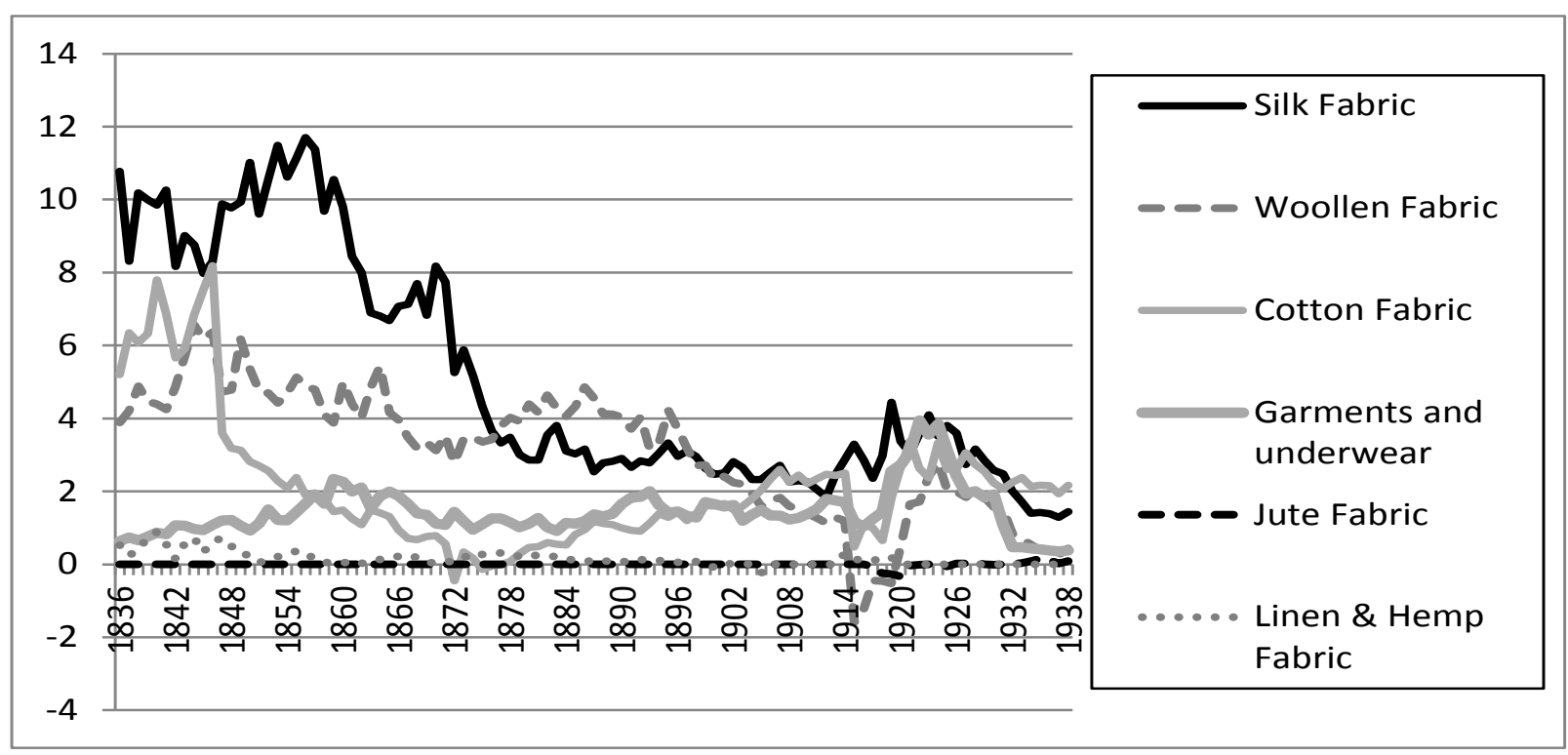

Source: Tableau général du commerce de la France avec ses colonies et les puissances étrangères (1836-1896); Tableau général du commerce et de la navigation (1897-1938); own calculations.

\footnotetext{
2 This industry, concentrated in the Lyon area, exported around 2/3 of its production until 1860,
} principally to the USA until the end of the 1850s, and later to Great Britain (see Verley, 1997). 


\section{Methodology to study stability of specialisation}

To study the stability of international specialisation we use an approach inspired by the seminal contributions of Pavitt (1989) and Cantwell (1989) in line with recent papers about modern specialisations (Alessandrini and Butuo, 2010; Chiappini, 2014). This approach uses the following regression equation:

$$
L F I_{i}^{\text {end }}=\alpha+\beta L F I_{i}^{\text {start }}+\varepsilon_{i} \quad i=1, \ldots, \mathrm{N} .
$$

The dependent variable is the value of $L F I_{i}$ at the end of one period. The key explanatory variable is the value of the same index for the same product at the beginning of the period, $\alpha$ is constant, $b$ is the key parameter of interest to be estimated and $\varepsilon$ is a residual term. In order to reduce the impact of year-to-year volatility, we take an arithmetic average of the values of the index in the current year and the preceding two years. The interpretation of the regression is as follows:

- If $\beta=1$ the specialization of the country is unchanged over time.

- If $\beta>1$ country has become more (less) specialised in sectors for which it already has a comparative advantage (disadvantage).

- If $0<\beta<1$, on average the sign of the specialization is still the same, but the value of the index has increased in sectors for which the initial value of the index was low and has decreased in the sectors for which the initial value of the index was high.

- If $\beta<0$ the sign of the LFI index has changed and the specialization has reversed.

- If $\beta=0$ there is no relationship between initial and final pattern of specialization.

Dalum et al (1998) point out that the interpretation of the $b$ coefficient does not allow a conclusion about the overall evolution of a country's specialization. However, more can be said about the distribution of specialization. Cantwell (1989) shows how it is possible to exploit the following relation deriving directly from the regression equation:

$$
\frac{\sigma_{\text {end }}^{2}}{\sigma_{\text {start }}^{2}}=\frac{\beta^{2}}{r^{2}}
$$

where $r^{2}$ is the squared correlation coefficient from the regression and $\sigma_{\text {end }}^{2}$ and $\sigma_{\text {start }}^{2}$ are respectively, the variance of the dependent and explanatory variable. The correlation coefficient is $r^{2}$ a measure of the mobility of sectors along the distribution between periods. A high value for this coefficient implies that products' relative position remains almost unchanged. By comparing the regression coefficient to $r$ three outcomes can arise:

- If $\beta=r$, the dispersion of the distribution of the index remains the same

- If $\beta>r$, dispersion increases, the degree of specialization has increased

- If $\beta<r$, dispersion decreases, the degree of specialization has decreased

This method thus provides a better understanding of a country's specialisation dynamics. 


\section{Estimations}

To begin our analysis of the stability of French textile specialisation between 1836 and 1938, we proceed by iteration. We consider all textile products (15 headings). We use as a first starting point the years 1836-1837. We then compare successive two-year periods to this initial period in order to detect a break point compared to the initial years. A break point appears when the estimate of $B$ becomes significantly different from 1 .

If we find a breakpoint, then we use the end period of the sub-sample as a new starting point for successive regressions. The null hypothesis is that $\beta$ re-sets to 1 after each break point. A useful metric for how fast specialisation is changing is the time between two break points. We can evaluate long-run stability with these data. Detected break points are presented in Table 1, which shows many interesting results.

Table 1: Estimations of stability in French textile specialisations between 1836 and 1938

\begin{tabular}{|c|c|c|c|c|c|c|c|}
\hline Start & End & & & & & & \\
\hline 1836-37 & 1838-39 & $1840-41$ & $1842-43$ & $1844-45$ & $1846-47$ & $1848-49$ & $1850-51$ \\
\hline$\beta$ & 1.038 & 1.062 & 0.944 & 1.008 & 0.943 & 0.988 & 1.003 \\
\hline$t^{*}$ & 1.627 & 1.778 & -1.311 & 0.132 & -1.431 & -0.188 & 0.038 \\
\hline$\beta / \mathrm{r}$ & 1.041 & 1.069 & 0.956 & 1.032 & 0.954 & 1.015 & 1.04 \\
\hline & $1852-53$ & $1854-55$ & $1856-57$ & 1858-59 & $1860-61$ & $1862-63$ & \\
\hline$\beta$ & 1.007 & 0.895 & 0.931 & 0.897 & 0.837 & 0.685 & \\
\hline$t^{*}$ & 0.079 & -1.139 & -0.631 & -0.991 & -1.754 & -3.54 & \\
\hline$\beta / \mathrm{r}$ & 1.062 & 0.955 & 1.011 & 0.972 & 0.902 & 0.756 & \\
\hline $1862-63$ & 1864-65 & $1866-67$ & $1868-69$ & $1870-71$ & 1872-73 & & \\
\hline$\beta$ & 1.052 & 0.991 & 0.935 & 0.889 & 0.788 & & \\
\hline$t^{*}$ & 0.995 & -0.194 & -1.896 & -2.155 & -6.03 & & \\
\hline$\beta / \mathrm{r}$ & 1.069 & 1.004 & 0.943 & 0.908 & 0.798 & & \\
\hline $1872-73$ & $1874-75$ & & & & & & \\
\hline$\beta$ & 0.912 & & & & & & \\
\hline$t^{*}$ & & & & & & & \\
\hline
\end{tabular}




\begin{tabular}{|c|c|c|c|c|c|c|c|}
\hline$\beta / \mathrm{r}$ & 0.919 & & & & & & \\
\hline 1874-75 & $1876-77$ & & & & & & \\
\hline$\beta$ & 0.852 & & & & & & \\
\hline$t^{*}$ & -3.953 & & & & & & \\
\hline$\beta / \mathrm{r}$ & 0.862 & & & & & & \\
\hline $1876-77$ & $1878-79$ & & & & & & \\
\hline$\beta$ & 0.832 & & & & & & \\
\hline$t^{*}$ & -3.24 & & & & & & \\
\hline$\beta / \mathrm{r}$ & 0.853 & & & & & & \\
\hline 1878-79 & 1880-81 & 1882-83 & 1884-85 & $1886-87$ & 1888-89 & 1890-91 & $1892-93$ \\
\hline$\beta$ & 0.972 & 1.073 & 0.998 & 1.068 & 0.988 & 0.981 & 0.989 \\
\hline$t^{*}$ & -0.845 & 1.487 & -0.047 & 1.022 & -0.209 & -0.288 & -0.138 \\
\hline$\beta / \mathrm{r}$ & 0.98 & $\begin{array}{ll} & 1.08 \\
8 & \end{array}$ & $\begin{array}{ll} & 1.01 \\
4 & \end{array}$ & $\begin{array}{ll} & 1.09 \\
5 & \end{array}$ & 1.01 & 1.01 & $\begin{array}{ll} & 1.02 \\
7 & \end{array}$ \\
\hline & 1894-95 & $1896-97$ & 1898-99 & $1900-01$ & $1902-03$ & 1904-05 & $1906-07$ \\
\hline$\beta$ & 0.99 & 0.984 & 0.846 & 0.819 & 0.814 & 0.748 & 0.802 \\
\hline$t^{*}$ & -0.145 & -0.207 & -1.747 & -1.614 & -1.397 & -1.707 & -1.178 \\
\hline & 1.02 & 1.021 & 0.904 & 0.913 & 0.945 & 0.918 & 1.005 \\
\hline & 1908-09 & $1910-11$ & & & & & \\
\hline$\beta$ & 0.712 & 0.596 & & & & & \\
\hline$t^{*}$ & -1.737 & -2.786 & & & & & \\
\hline$\beta / \mathrm{r}$ & 0.93 & 0.793 & & & & & \\
\hline $1910-11$ & $1912-13$ & $1914-15$ & $1916-17$ & & & & \\
\hline$\beta$ & 1.084 & 0.763 & 0.456 & & & & \\
\hline$t^{*}$ & 2.376 & -1.897 & -3.684 & & & & \\
\hline$\beta / \mathrm{r}$ & 1.091 & 0.886 & 0.701 & & & & \\
\hline
\end{tabular}




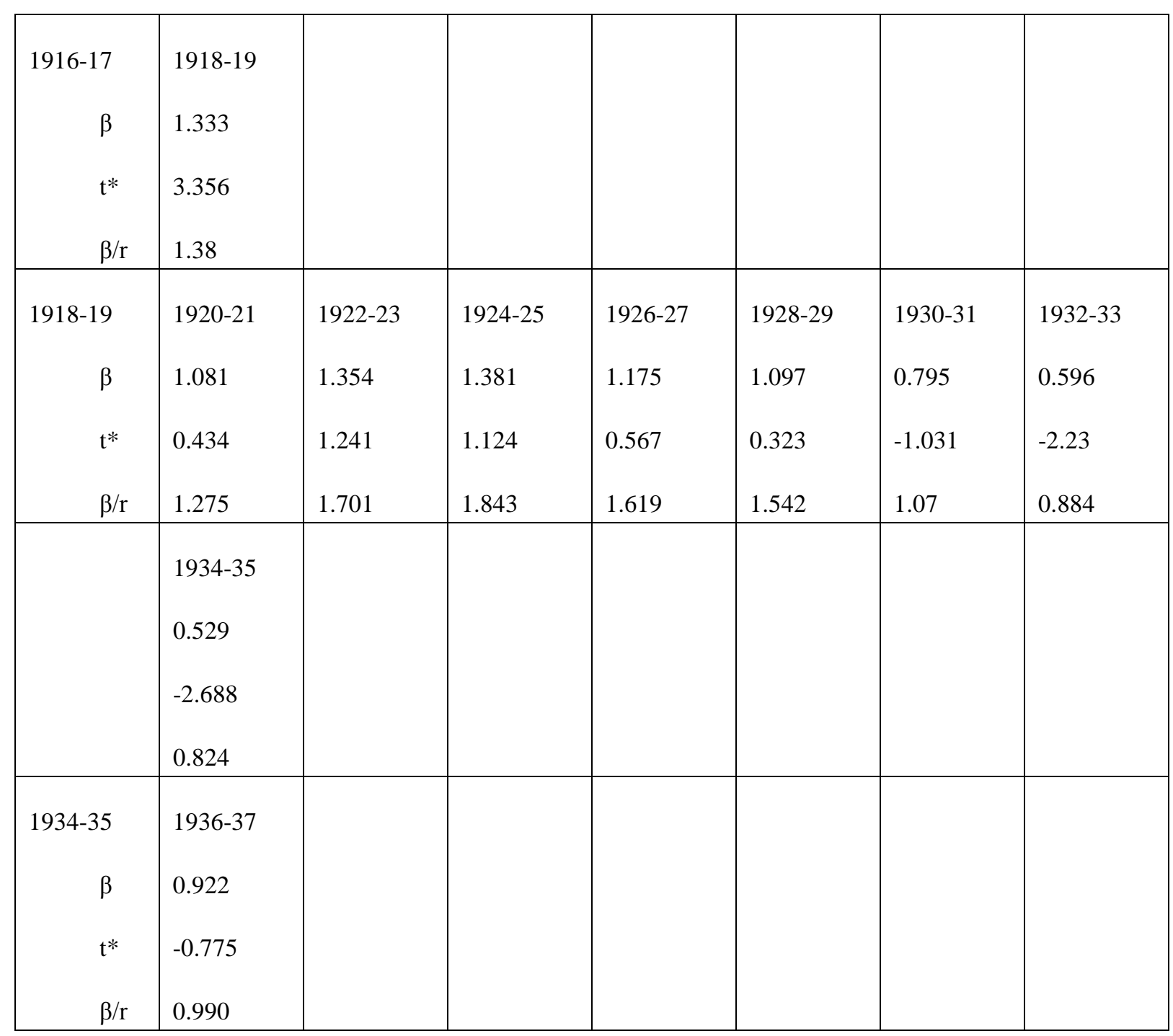

Exogenous shocks have impacts on the stability of textile specialisation. Between 1836 and 1861 French textile specialisation appears to have been completely stable (the null hypothesis $B=1$ cannot be rejected). Between 1836-37 and 1859-61, B/r remains very near 1 , indicating strong stability in French specialisation during a quarter of a century. During this period French trade policy was particularly protectionist with prohibitions on imports of finished textiles (according to Cadier (1988) the end of these prohibitions only became effective in October 1861). Trade liberalisation at the start of the 1860 s was a first shock for textiles and the "cotton famine" during the American civil war was a second which had an impact on the structure of specialisation.

Taking $1862-63$ as a new starting point, $B$ is equal to 1 at a high level of significance in the 1860s. The regression coefficient $B$ remains close to 1 until $1870-71$. The decrease in the $B / R$ ratio shows that there was a textile de-specialisation during the 1860s. The Franco-Prussian Treaty of Frankfurt in May 1871 led to the loss of Alsace and Lorraine which deprived France of the dynamism of cotton centres such as Mulhouse. 
Computing the regression every two years leads to the conclusion that there was great instability in the structure of specialisation during the 1870s. The regression coefficient $B$ remains close to 1 only when we consider $1878-1879$ as a new starting point. The decrease in specialisation during the 1870s accompanies an (economically) significant change in the distribution of specialisation indices as seen from the fact that the values of $b / r$ are below 1 for all the periods considered.

From our estimates of $B$, a period of stability in specialisation can be identified between 1878 79 and 1910-1911 without any clear conclusion concerning changes in $8 / r$. Taking a new starting point in 1910-1911, we reject the hypothesis of stability during WWI (for textiles during WWI see Aftalion, 1924, a pioneer in the use of statistics).

Between 1918-19 and the start of the 1930s, French textile specialisation appears to have been completely stable (the null hypothesis $B=1$ cannot be rejected). $b / r$ becomes significantly greater than 1, indicating an increasing of the degree of specialisation in textiles. This rise appears curious for a modern economy. At the end of the 1930s, textile specialisation became unstable.

\section{Trade policy as a determinant of the Lafay index}

In order to test the impact of trade policy on specialisation we apply the following regression to panel data including six textile sectors (silk, cotton and woollen fabrics, garments, wool and silk as raw materials) between 1850 and 1913:

$$
\begin{aligned}
& \mathrm{LFI}_{i, t}=\mathrm{b} 1+\mathrm{b} 2 \mathrm{CT}_{\mathrm{i}, \mathrm{t}-1}+\eta_{i, t} \\
& \mathrm{LFI}_{\mathrm{i}, \mathrm{t}} \text { is the Lafay Index for sector } \mathrm{i} \text { at time } \mathrm{t} \\
& \mathrm{CT}_{\mathrm{i}, \mathrm{t}-1} \text { is the customs tariff for sector } \mathrm{i} \text { at time t-1 }
\end{aligned}
$$

The results of this regression are:

$$
\mathrm{LFI}_{\mathrm{i}, \mathrm{t}}=0.171^{* * *} \mathrm{CT}_{\mathrm{i}, \mathrm{t}-1}-0.353, \quad \mathrm{R}^{2}=0.135 \quad \mathrm{~F}=55.46 \quad \mathrm{n}=355
$$

We obtain a positive significant influence of tariffs on specialisation which confirms and completes the previous results. These results contribute to explaining the stability of the structure of the Lafay index, particularly from 1880 to 1910 .

\section{.5. Intra-industry trade in textile}

In order to shed a different light on specialisation dynamics and competitiveness we decided to measure intra-industry trade (IIT) at different levels of disaggregation and to identify the determinant of IIT. 


\section{Grubel and Lloyd Index}

Although IIT was first conceptualised by Verdoorn in 1960, it constitutes one of the main contributing factors to French foreign trade before WWI. In a pioneering paper Becuwe (1989) measured this phenomenon at an aggregate level for France.

For each product and each year, a Grubel and Lloyd Index has been calculated:

$$
G L_{i}=1-\frac{\left|X_{i}-M_{i}\right|}{X_{i}+M_{i}} \quad \text { (where } \mathrm{i} \text { is the product). }
$$

Where $\mathrm{xi}$ and $\mathrm{mi}$ are exports and imports of product i.

For primary products (silk, wool and cotton) the level of IIT is low in the 1850s and increases after trade liberalisation. France's exports increased, contrary to what the old international division of labour would have predicted. For silk and wool IIT remained stable - at a high level - until WWI. The situation was much more heterogeneous during the interwar period.

Figure 9: Percentage of intra-industry trade for primary products

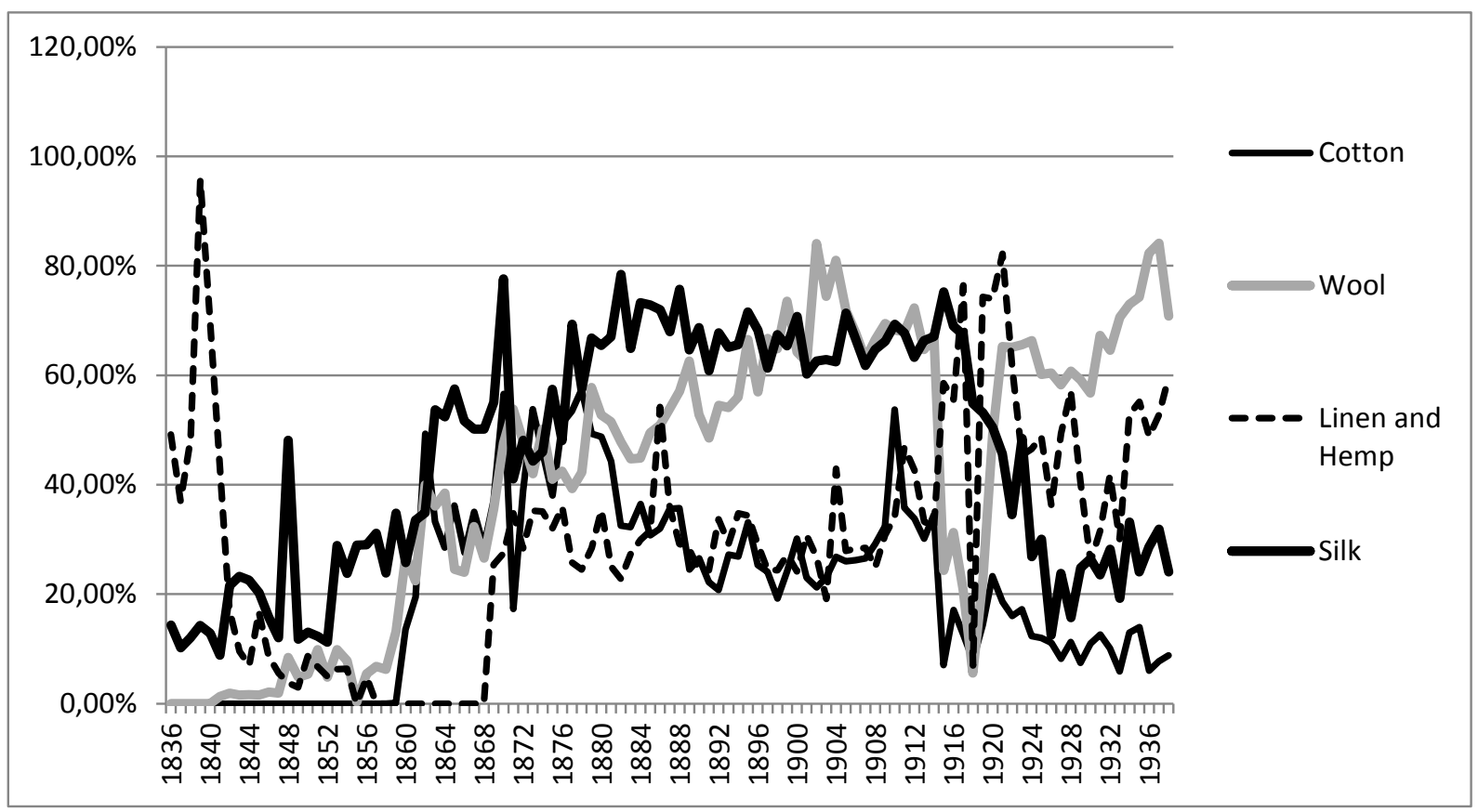

Source: Tableau général du commerce de la France avec ses colonies et les puissances étrangères (1836-1896); Tableau général du commerce et de la navigation (1897-1938); own calculations. 
Figure 10: Percentage of intra-industry trade for finished products

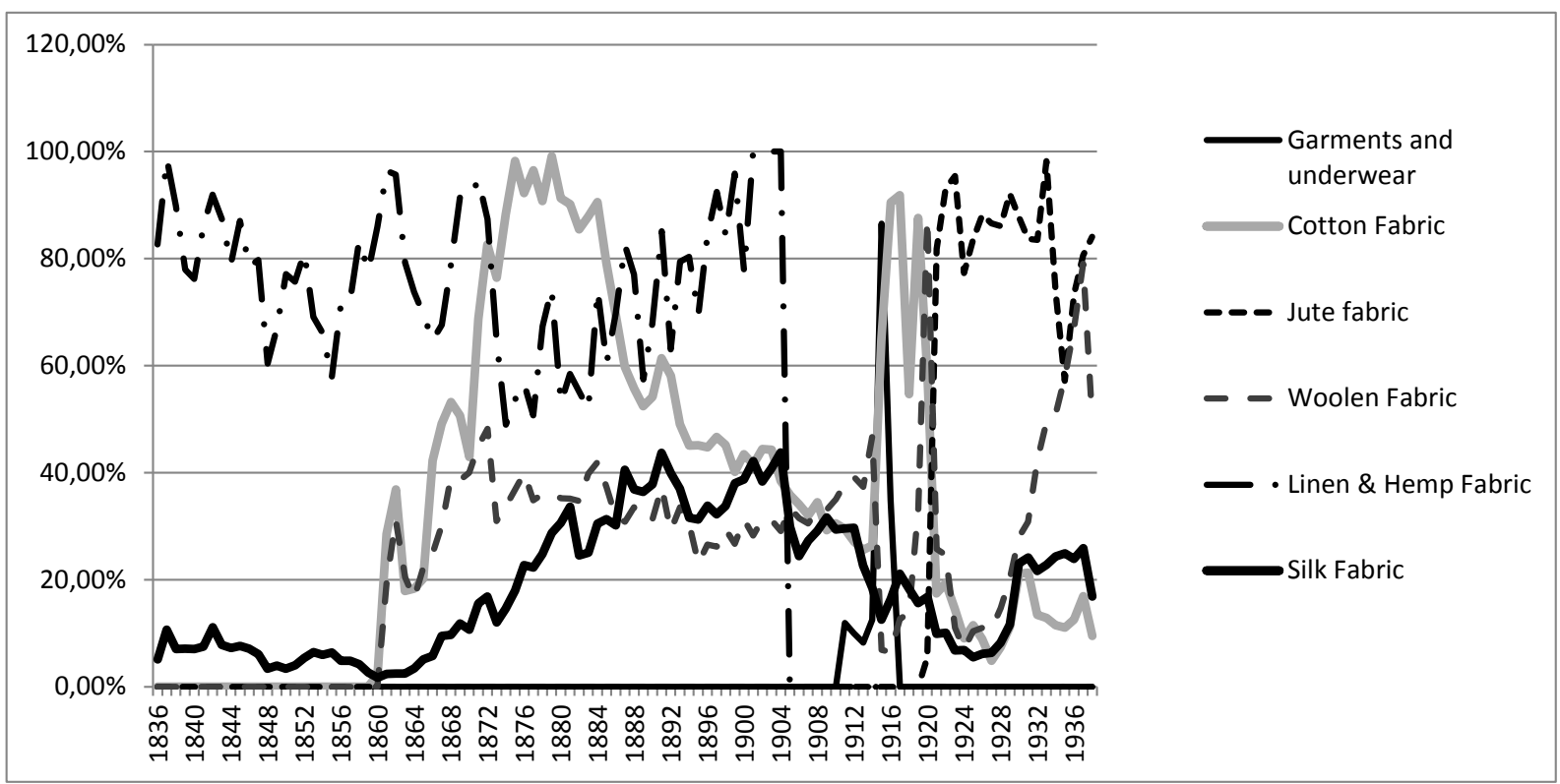

Source: Tableau général du commerce de la France avec ses colonies et les puissances étrangères (1836-1896); Tableau général du commerce et de la navigation (1897-1938); own calculations.

At a desagregated level, IIT seems to have been correlated with trade policies. For textiles 1860 appears to have been a turning point. Most cotton and woollen fabrics, which were banned prior to the 1860 treaty, were immediately imported in large quantities from Britain after the treaty (Cadier, 1988). The treaty introduced a moderate $15 \%$ tariff on imports of cotton, woollen and linen fabrics (10\% from October 1864). The treaty reduced the tariff on silk fabric to $3-4 \%$ for ribbons and made pure silk fabric duty-free. More generally, in the 1860s the increase in imports thanks to trade liberalisation explains IIT in manufactured products (this is true for metal tools and prepared hides). During the 1880s and the 1890s manufacturing sectors were characterised by a high intensity of IIT in a new strategic and negotiated trade regime. Curiously IIT decreases in the 1900s for silk fabrics, wool and leather articles.

Garments, underwear and trinkets were not concerned by IIT except for short periods (for example WWI for garments \& underwear): for these products French imports were weak over the long term.

\section{Trade policy as a determinant of intra-industry trade in textiles}

In order to understand the development of IIT at a macroeconomic level we compute a regression of IIT at time $t$ on the average tariff ( $T$ ) at time $t-1$ and the spread between GDP per capita in France and GDP per capita of its trade partners at time t-1, thus testing Linder's hypothesis. Linder (1961) first conjectured that the congruence of production and consumption patterns leads countries 
with similar per capita income to trade more with one another. However Linder's test appears to be more robust at a more aggregated level.

We run regressions of the following form:

$G L i_{t}=b_{0}+b_{1}($ year $)+b_{2}[G G a p t-1]+b_{3}\left(T i_{t-1}\right)+\eta_{i, t}$

$\mathrm{GLi}_{\mathrm{t}}$ is the Grubel and Lloyd index for sector $\mathrm{i}$ at time $\mathrm{t}$

GGapt is the value of the difference between French GDP per capita and the GDP per capita of its trade partners. The GDP per capita of trade partners is weighted by the percentage of French exports going to each partner. Using the Maddison Project Database we include 12 partners, representing $75.88 \%$ of French exports (UK, Belgium, Germany, US, Switzerland, Italy, Spain, Netherlands, Greece, Denmark, Sweden, Norway).

$\mathrm{Ti}_{\mathrm{t}-1}$ is the tariff level in sector $\mathrm{i}$ at time $\mathrm{t}-1$

Table 2: Estimations for determinants of IIT (1850-1913)

\begin{tabular}{|c|c|c|c|c|c|c|c|}
\hline GLi index & Year & GGapt-1 & Tt-1 & Cste & $R^{2}$ & $\mathrm{~F}$ & Period \\
\hline Silk fabric & $\begin{array}{l}0.15 \\
(1.25)\end{array}$ & $\begin{array}{l}-0.03 * * * \\
(-3.54)\end{array}$ & $\begin{array}{l}-0.83 * * * \\
(-3.67)\end{array}$ & $\begin{array}{l}-2.87 \\
(-0.73)\end{array}$ & 0.81 & 83.05 & $\begin{array}{l}1851- \\
1913\end{array}$ \\
\hline $\begin{array}{l}\text { Woollen } \\
\text { fabric }\end{array}$ & $\begin{array}{l}0.27^{*} \\
(1.87)\end{array}$ & $\begin{array}{l}0.004 \\
(0.43)\end{array}$ & $\begin{array}{l}-1.78 * * * \\
(-4.66)\end{array}$ & $\begin{array}{l}51.41^{* * *} \\
(7.80)\end{array}$ & 0.34 & 8.37 & $\begin{array}{l}1862- \\
1913\end{array}$ \\
\hline $\begin{array}{l}\text { Cotton } \\
\text { fabric }\end{array}$ & $\begin{array}{l}1.77^{* * *} \\
(-3.71)\end{array}$ & $\begin{array}{l}0.08 * * * \\
(-2.60)\end{array}$ & $\begin{array}{l}1.27 \\
(1.01)\end{array}$ & $\begin{array}{l}15.29 \\
(0.64)\end{array}$ & 0.26 & 5.61 & $\begin{array}{l}1862- \\
1913\end{array}$ \\
\hline Clothes & $\begin{array}{l}-0.015 \\
(-0.17)\end{array}$ & $\begin{array}{l}-0.012^{*} \\
(-1.99)\end{array}$ & $\begin{array}{l}-0.25 * * * \\
(-2.60)\end{array}$ & $\begin{array}{l}3.75 \\
(1.36)\end{array}$ & 0.42 & 13.98 & $\begin{array}{l}1851- \\
1913\end{array}$ \\
\hline Wool & $\begin{array}{l}0.63^{* * *} \\
(4.46)\end{array}$ & $\begin{array}{l}-0.018^{*} \\
(-1.84)\end{array}$ & $\begin{array}{l}-0.68 * * * \\
(-5.85)\end{array}$ & $\begin{array}{l}15.25^{* * *} \\
(3.97)\end{array}$ & 0.91 & 189.75 & $\begin{array}{l}1851- \\
1913\end{array}$ \\
\hline Silk & $\begin{array}{l}0.23 \\
(0.84)\end{array}$ & $\begin{array}{l}-0.0095 \\
(-0.61)\end{array}$ & $\begin{array}{l}-68.4 * * * \\
(-2.82)\end{array}$ & $\begin{array}{l}53.17^{* * *} \\
(5.93)\end{array}$ & 0.64 & 34.79 & $\begin{array}{l}1851- \\
1913\end{array}$ \\
\hline
\end{tabular}

*** significant at $1 \% ; *$ significant at $5 \%$ 
The major results are: a negative relationship between IIT and lagged tariffs for all sectors except cotton fabric. The cotton famine of the 1860 s partly explains this result. In fact, Linder's hypothesis appears to be valid for five sectors (silk and cotton fabrics, clothes, wool and silk), but the coefficient is significant only for four sectors. Considering the coefficient values the impact of tariffs appears to be more important.

We performed the following regression to panel data with the six products together:

$$
\begin{aligned}
G L i_{t}= & b_{0}+b 1\left(T i_{t-1}\right)++\eta_{i, t} \\
G L t & =-1.045^{* * *} \mathrm{CTt}-1+46.81, \mathrm{n}=326, \mathrm{R}^{2}=0.106
\end{aligned}
$$

At a more global level we obtain the same negative relationship between IIT and lagged tariffs (the coefficient is significant at $1 \%$ ). Trade policy significantly influenced IIT dynamics during the first globalisation.

\section{.6. Effective protection of textiles}

After working as a consultant in Australian textiles in the early 1960s, Corden shows the importance of vertical relationships among products and the opportunity for effective protection. The latter appears as a trade policy strategy whose objective is to increase the competitiveness of national products by reducing tariffs on inputs. Corden (1971) analyses the general equilibrium implications of tariffs and highlights the crucial issue of the difference between tariffs on inputs and final products.

Following this idea, we propose to study changes in vertical tariffs on textiles in order to establish the reality of the effective protection approach. We focus on the crucial period of the first globalisation when new competitors emerged in textiles.

As shown in Figure 3, the percentage of primary textiles in total imports is very high, at around $30 \%$ between the 1840 s and the 1860 s and around $20-25 \%$ between the 1870 s and WWI. According to Markovitch (1966) French national production of raw wool declined from 60,000 tonnes on average between 1855 and 1864 to 40,100 tonnes between 1895 and 1904; over the same period raw wool imports went up from 55,200 tonnes to 233,135 tonnes. 
Figure 11: Changes in average tariffs by type of product (in \%)
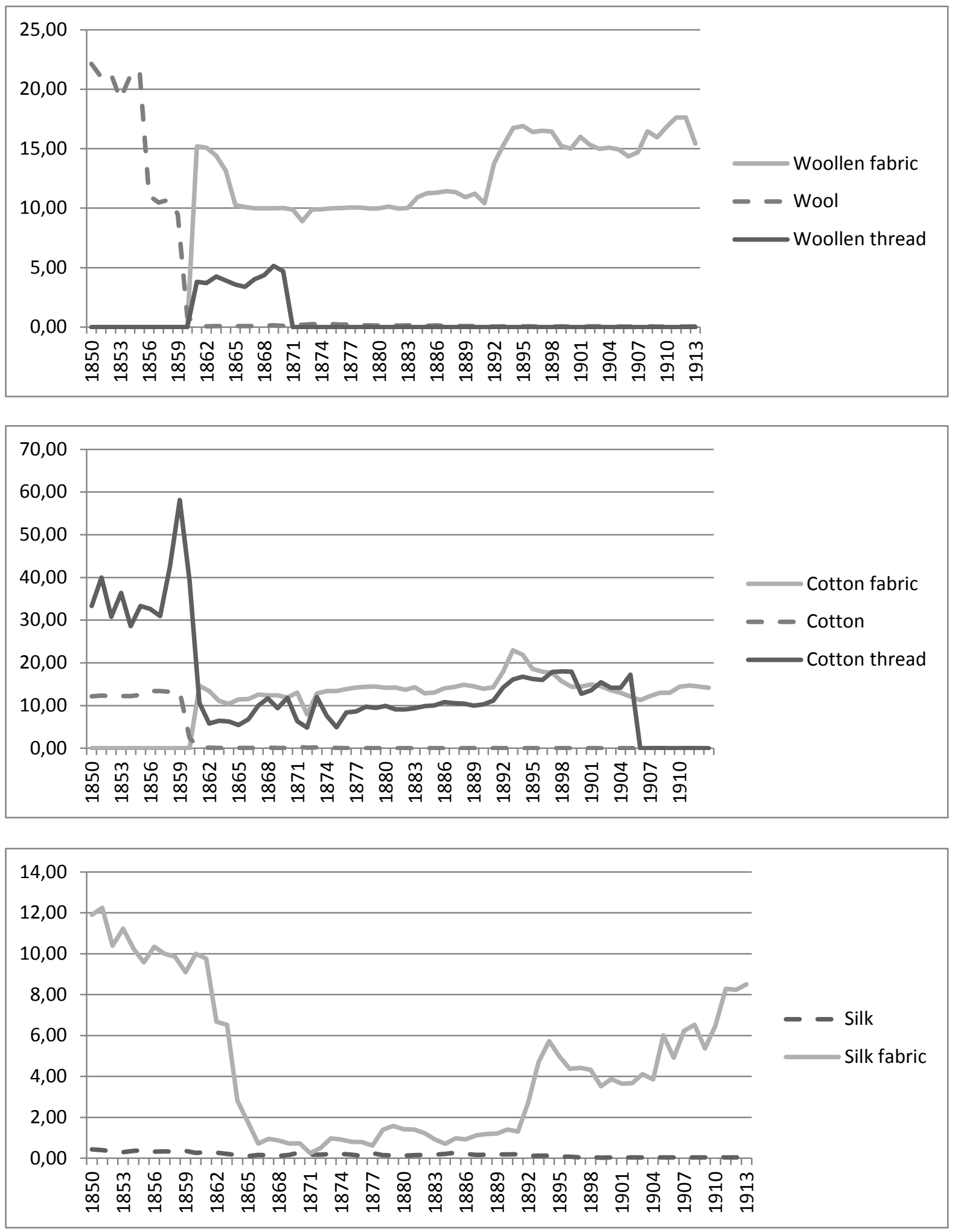
For wool and cotton, tariffs on primary products decreased at the end of the 1850s, respectively from $21.6 \%$ in 1855 , to $9.5 \%$ in 1859 and $0 \%$ in 1861 and from $13 \%$ in 1859 to $0 \%$ in 1861. The General Tariff Document of 1860 fixed very low tariffs on raw silk, cotton and wool (this was true until WWI). This implied the removal of all prohibitions on manufactured items and their replacement by rights which could not exceed $30 \%$ (and then $25 \%$ in 1864). The Treaty concluded for 10 years reduced the average duty rate of $11.8 \%$ in 1859 to $5.3 \%$ in 1861 . For woollen fabrics, the first tariff was established at 15\% in 1860 and around 10\% thereafter until the introduction of Méline's Tariff; for cotton, tariffs went up to $10 \%$ between the 1860 s and 1892 . For silk, the tariff level was reduced from $12 \%$ to $1 \%$ between 1850 and the middle of the 1860 s. Considering this effective protection dimension the free trade philosophy of the 1860 commercial treaty can be questioned. After Méline, the tariffs for silk and woollen fabrics, sectors that experienced difficulties in the 1880s, were significantly increased (see Figure 11 ). For cotton, the tariff went up to $23 \%$ in 1893 , but the rise was not maintained. It decreased immediately afterwards. These practices reveal specific trade actions by industrial sectors to try to support their level of competitiveness.

As far as correlations between tariffs are concerned, a negative correlation may be established between wool and woollen fabrics $(-0.80)$, between cotton and cotton fabrics $(-0.88)$, but this is not true for silk $(+0.39)$. These results confirm the effective protection approach. The negative correlation between silk fabric and cotton fabric $(-0.64)$ and silk fabric and woollen fabric $(-0.41)$ shows the existence of a specific trade policy by sector in order to sustain industrial competitiveness.

Table 3: Correlation between average tariff rates between 1850 and 1913

\begin{tabular}{|c|c|c|c|c|c|c|}
\hline$r$ & Cotton & Wool & Silk & $\begin{array}{l}\text { Cotton } \\
\text { fabric }\end{array}$ & $\begin{array}{l}\text { Woollen } \\
\text { fabric }\end{array}$ & Silk fabric \\
\hline Cotton & 1 & 0.93 & 0.74 & -0.88 & -0.85 & 0.73 \\
\hline Wool & & 1 & 0.72 & -0.83 & -0.80 & 0.70 \\
\hline Silk & & & 1 & -0.73 & -0.85 & 0.39 \\
\hline $\begin{array}{l}\text { Cotton } \\
\text { fabric }\end{array}$ & & & & 1 & 0.89 & -0.64 \\
\hline $\begin{array}{l}\text { Woollen } \\
\text { fabric }\end{array}$ & & & & & 1 & -0.41 \\
\hline Silk fabric & & & & & & 1 \\
\hline
\end{tabular}

In order to show - using another method - the effect of the effective protection approach on competitiveness we estimate the regression between export unit values for textile fabrics and tariffs 
on raw products for silk, wool and cotton. We thus consider vertical relationships among textile products directly. We perform the following regression for the period between 1850 and 1913:

$$
\mathrm{EUV}_{\mathrm{i}, \mathrm{t}}=\mathrm{b} 1+\mathrm{b} 2 \mathrm{CT}_{\mathrm{i}, \mathrm{t}-1}+\eta_{i, t}
$$

$E U V_{i, t}$ is the export unit value in sector $i$ at time $t$ (value of total exports divided by the quantity).

$T_{t-1}$ is the tariff level in sector $i$ at time $t-1$

Table 4: Regression between export unit values for textile fabrics and tariffs on raw products

\begin{tabular}{|c|c|c|c|c|c|c|c|}
\hline $\begin{array}{l}\text { Export } \\
\text { Unit } \\
\text { Value }\end{array}$ & Constant & $\begin{array}{l}\text { Customs } \\
\text { tariff for } \\
\text { silk }\end{array}$ & $\begin{array}{l}\text { Customs } \\
\text { tariff for } \\
\text { wool }\end{array}$ & $\begin{array}{l}\text { Customs } \\
\text { tariff for } \\
\text { cotton }\end{array}$ & Period & $\mathrm{R}^{2}$ & $\mathrm{~F}$ \\
\hline Silk fabric & 52.13 & $\begin{array}{l}223^{* * *} \\
(8.57)\end{array}$ & & & $\begin{array}{l}1850- \\
1913\end{array}$ & 0.54 & 73.42 \\
\hline $\begin{array}{l}\text { Woollen } \\
\text { fabric }\end{array}$ & 12.01 & & $\begin{array}{l}35.5^{* * *} \\
(4.16)\end{array}$ & & $\begin{array}{l}1861- \\
1913\end{array}$ & 0.25 & 17.30 \\
\hline $\begin{array}{l}\text { Cotton } \\
\text { fabric }\end{array}$ & 6.66 & & & $\begin{array}{l}8.06 * * * \\
(4.11)\end{array}$ & $\begin{array}{l}1861- \\
1913\end{array}$ & 0.25 & 16.90 \\
\hline
\end{tabular}

$* * *$ : significant at $1 \%$

We establish a positive and significant link between export unit values for finished textile products and lagged tariffs on raw textiles. A decrease in raw textile tariffs reduces production costs and contributes to a fall in the price of finished exports.

All of these arguments suggest that successive French governments adopted an effective protection approach during the first globalisation and tried to support textile specialisations by a "vertical strategy". 


\section{Conclusion}

By using an original dataset the paper highlights the long-term contribution of textiles to French international trade. Annual data permit a detailed analysis of changes caused by historicallyidentified shocks including silkworm diseases, cotton famines and the Franco-Prussian war. At the beginning of the period, France was largely specialized in finished textiles (silk, woollen and cotton fabrics). After the trade liberalisation of the 1860s, these specialisations declined. But at the end of the $19^{\text {th }}$ and the beginning of the $20^{\text {th }}$ century the old textile industry continued to prosper in France (as it did in the UK) despite the challenges of low-wage competition from new competitors.

In line with Marshall's view, recent papers explain UK resistance - considering horizontal relationships in Lancashire - in terms of the benefits of external economies of scale. According to Broadberry and Marrison (2002), Balderston (2010), Craft and Wolf (2013) Lancashire's competitive edge was based on a combination of the deep pool of skilled labour, energy, satellite industries, bankers, and insurance agents.

In the French case the government's vertical trade policy sustained textile development. The paper shows, in an original manner, the major influence of trade policy on French international trade in textiles during the first globalisation. Tariff is a crucial determinant of specialisation measured by the Lafay Index. Tariff is a major determinant of intra-industry trade in textiles. By analysing changes in tariffs between raw and finished textiles and decorrelation between tariffs we show that the effective protection approach was applied by successive French governments in order to sustain the industrial competitiveness of textiles. This was particularly true in the 1860s and the 1890s. Trade policy slowed textile de-specialisation until WWI. More generally it is noticeable that the list of France's major foreign exchange-earning sectors did not differ markedly from one end of the period to the other. In 1913, France's main exporting industries were still those which had become famous under the Second Empire, only their share of total trade had dwindled (Becuwe et al 2015).

In order to complete the analysis of French and British industrial adaptation in the face of new competitors during the first wave of globalisation, it would be interesting to conduct research into long-term changes in the positioning of export quality by computing export unit values for each specialisation in each country.

The effective protection approach could be re-introduced into the tariff-growth paradox literature. By using aggregated tariff averages (either at the global or at the ISIC sectorial level) Bairoch (1972), O'Rourke (2000), Clemens and Williamson (2001), Lehman and O'Rourke (2008), Tena-Junguito (2009), Schularick and Solomou (2011) show a positive correlation between tariffs and GDP per capita for European and Europeanised countries. Considering effective protection in panel data with the same large sample could enable the debate to be renewed when the desegregated database becomes available. 


\section{References}

Aimar, T., Bismans, F., Diebolt, C., 2016. Business Cycles in long Run History, Berlin, Springer.

Alessandrini, M., Butuo, M.E., 2010. The trade specialisation of SANE: Evidence from manufacturing industries. The European Journal of Comparative Economics. 7 (1), 145-178.

Allen, R., 2009. The British Industrial Revolution in Global Perspective. Cambridge University Press.

Aftalion, A., 1904. La crise de l'industrie linière et la concurrence victorieuse de l'industrie cotonnière, Paris, Larose.

Aftalion, A., 1924. L'industrie textile en France pendant la guerre, Paris, PUF.

Asselain, J-Ch. and Blancheton B. 2005, « Dynamique de l'ouverture internationale. Paradoxes, enjeux, éléments d'interprétation à partir du cas de la France. "Economies et Sociétés, série HEQ. 1, 49-179

Balassa, B., 1965. Trade Liberalization and Revealed Comparative Advantage. Manchester School of Economics and Social Studies. 33, 99-123.

Bairoch, P. 1993, La France dans le contexte international: politique commerciale et commerce extérieur 1890-1990. In Le commerce extérieur français de Méline à nos jours, Paris, CHEFF, pp. 3-33.

Balderston, R., 2010, The economics of abundance: coal and cotton in Lancashire and the world, Economic History Review, 63, 569-590.

Becuwe, S., 1989, Les déterminants macro-économiques du commerce intra-branche de la France : une approche de long terme (1850-1980), Revue Economique, vol.40 (5), pp.863-886.

Becuwe, S., Blancheton, B., 2014. The dispersion of customs tariffs in France between 1850 and 1913: discrimination in trade policy. Research in Economic History. 30. 163-183.

Becuwe, S., Blancheton, B., Meissner., 2015. Stages of diversification: France, 1836-1938, NBER Working Paper Series, $n^{\circ} 21777$.

Betran, C., Huberman, M., 2016, International Competition in the first wave of globalization: new evidence on the margins of trade, Economic History Review, 69(1), 258-287.

Braodberry, S., Marrison, A, External economies of scale in the Lancashire cotton industry, 1900-1950, Economic History Review, LV, 51-77.

Broder. A., 1993. Le tarif de 1892 et les industries nouvelles : une première approche, in Le commerce extérieur français de Méline à nos jours, Paris, CHEFF, pp. 53-65. 
Broder, A., 2006. Biens d'équipement et commerce extérieur: 1874-1913 (1920-1930) quelques réflexions sur une faiblesse structurelle de l'économie française, in : L'économie française dans la compétition internationale au XXe siècle, CHEFF, Paris, pp.37-88.

Cadier, G., 1988. Les conséquences du traité de 1860 sur le commerce franco-britannique, Histoire, Economie et Société, n³, pp.355-380.

Cameron, R.E., 1961. France and the Economic Development of Europe (1800-1914), Princeton, Princeton University Press.

Cantwell, J., 1989, Technological innovation and multinational corporations. Oxford: Blackwell Publisher.

Caron, F., 1981, Histoire économique de la France, XIXe-XXe siècles, Paris, Colin.

Cazals, R., 1983, Les révolutions industrielles à Mazamet, 1750-1900, La DécouverteMaspero/Privat.

Chassagne, S., 1991. Le coton et ses patrons. France, 1760-1840, Editions de l'EHESS, Paris.

Chassagne, S., 2012. Veuve Guérin et fils: Banque et soie, une affaire de famille, Saint Chamond-Lyon (1716-1932), Editions BGA, Permezel.

Chiappini, R., 2014. Persistence vs. Mobility in Industrial and Technological Specializations: Evidence from 11 Euro Area Countries. Journal of Evolutionary Economics, 24 (1), 159-187.

Corden, W., 1971. The Theory of Protection, Oxford, Clarendon.

Crafts, N., Wolf, N., 2013, The location of the UK cotton textiles industry in 1838: a quantitative analysis, EHES, Working Paper Series in Economic History, ${ }^{\circ} 147$

Crouzet, F., 2003. The historiography of French economic growth in the nineteenth century, Economic History Review, 56 (2), 215-242.

Dalum, B., Laursen, K., Villumsen, G., 1998. Structural change in OECD export specialization patterns: de-specialization and 'stickiness'. International Review of Applied Economics, 12(3), 423443.

Daumas, J-C., 2004, les territoires de la laine. L'industrie lanière en France au XIXe siècle. Villeuneuve d'Ascq, PU du Septentrion.

Dedinger, B. (2012), "The Franco-German trade puzzle: an analysis of the economic consequences of the Franco-Prussian war". Economic History Review, 65, pp. 1029-54.

Dormois, J-P., 2006. The impact of late-nineteenth century tariffs on the productivity of European industries (1870-1930), in: Dormois, J-P., Lains, P., (Eds.), Classical Trade Protectionism 1815-1914, Routledge, London and New York, pp. 160-92. 
Dormois, J-P., 2009. La défense du travail national? L'incidence du protectionnisme sur l'industrie en Europe (1870-1913), PUPS, Paris.

Federico, G., Wolf, N., 2011. Comparative Advantages in Italy : a Long-run perspective, Quaderni di Storia Economica, n9, Banca d'Italia.

Fock Ah Chuen, M., 1997. Etat, production et exportation cotonnières, industrie textile et développement économique. Une histoire économique du coton/textile dans le monde. Thèse pour le doctorat es sciences économiques, Université de Montpellier I.

Fohlen, C., 1956. L'industrie textile en France au temps du Second Empire, Paris, Plon.

Gayot., G., 1998. Les draps de Sedan 1646-1870, Paris, EHESS.

Klein, J-F., 2005. Réseaux d'influences et stratégie coloniale. Le cas des marchands de soie Iyonnais en mer de Chine (1843-1906), Outre-Mers, vol.92, n³46, pp.221-256.

Lafay, G., 1992. The Measurement of Revealed Comparative Advantage, in : Dagenais M.G and Muet P.A (Eds), International Trade Modeling, Chapman \& Hall, London, pp.209-234.

Léon, P., 1974. Géographie de la fortune et des structures sociales à Lyon au XIXe siècle 18151914. Lyon, Université Lyon II, Centre d'Histoire économique et sociale de la région de Lyon.

Lévy-Leboyer, M., Bourguignon, F., 1990. The French Economy in the Nineteenth Century: An Essay in Econometric Analysis, Cambridge University Press, Cambridge.

Linder, S.B., 1961. Essay on trade and Transformation. New York. Wiley and Sons.

Lucas, R., 1988. On the mechanics of economic development. Journal of Monetary Economics, $22,3-42$.

Maddison, A., 2001, L'économie mondiale. Une perspective millénaire, OCDE.

Markovitch T, 1965, Le produit physique de l'économie française, Cahiers de l'ISEA, série AF, $n^{\circ} 4$.

Markovitch, T., 1966. L'industrie française de 1789 à 1964. Conclusions générales. Cahiers de I'ISEA.

Pavitt, K., 1989. International patterns of technological accumulation, in: Hood, N., Vahlne J.E., (Eds), Strategies in global competition, Croom Helm Publisher, London, pp.126-151.

Prat-Sabartès, M., Between the firm and the market: an international comparison of the commercial structures of the cotton industry (1820-1939), Business History, 51, 181-209.

Reynaud, B., 1991. L'industrie rubanière dans la région stéphanoise 1895-1975. Saint-Etienne, Publications de l'Université de Saint-Etienne. 
Rioux, J-P., 1971. La révolution industrielle 1780-1880., Paris, Seuil.

Verley, P., 1997. L'échelle du monde, Gallimard, Paris.

Verley, P., 2006, "L'insertion de la France dans les réseaux internationaux de l'échange (fin XIXe - début XXe siècle ", in L'économie française dans la compétition internationale au XXe siècle, Paris, CHEFF, pp.15-36.

Weiller, J., 1971. Long-Run Tendencies in Foreign Trade, with a Statistical Study of French Trade Structure 1871-1939, Journal of Economic History, 31 (4), 804-821.

Young, A., 1991. Learning by doing and the dynamic effects of international trade. The Quarterly Journal of Economics, 106(2), 369-405.

Zaghini, A., 2005. Evolution of Trade Patters in the new EU member States. Economics of Transition, 13 (4), 629-658. 


\title{
Cahiers du GREThA \\ Working papers of GREThA
}

\section{GREThA UMR CNRS 5113}

\author{
Université de Bordeaux \\ Avenue Léon Duguit \\ 33608 PESSAC - FRANCE \\ Tel : +33 (0)5.56.84.25.75 \\ Fax : +33 (0)5.56.84.86.47
}

http://gretha.u-bordeaux.fr/

\begin{abstract}
Cahiers du GREThA (derniers numéros - last issues)
2016-03 : DEGUILHEM Thibaud, FRONTENAUD Adrien : Régimes de qualité de l'emploi et diversité des pays émergents

2016-04 : BENABDEJLIL Nadia, LUNG Yannick, PIVETEAU Alain : L'émergence d'un pôle automobile à Tanger (Maroc)

2016-05: MAICHANOU Ahamadou, La micro-assurance agricole indicielle: raisons et conditions d'exercice au Niger

2016-06: MAICHANOU Ahamadou, Déterminants d'emprunt et de risque de crédit des ménages ruraux au Niger

2016-07: BERTHE Alexandre, Mesurer les inégalités d'accès à l'eau et à l'assainissement dans le Nord et le Nordeste du Brésil : quels enseignements en matière de justice sociale?

2016-08 : LORENZON Emmanuel, Collusion with a Greedy Center in Position Auctions

2016-09: DELFAUD Pierre, Retour sur une expérience unique d'interventionnisme en économie de marché: La Politique agricole commune européenne (1955-2015)

2016-10: MUTASCU Mihai, PEREAU Jean-Christophe, URSU Eugen: A Wavelet Analysis of the Environmental Kuznets Curve in France

2016-11 : LISSONI Francesco : Migration and Innovation Diffusion: An Eclectic Survey

2016-12 : BONIN Hubert : Les paradoxes de l'économie maritime française au début du XXIe siècle

2016-13 : CASTIGLIONESI Fabio, NAVARRO Noémi : (In)Efficient Interbank Networks

2016-14 : PEREAU Jean-Christophe, MOUYSSET Lauriane, DOYEN LUC: Groundwater management in food security context

2016-15: FAURE Yves-André: Institutions locales et résistances au test du VIH/sida. Quelques leçons d'une enquête dans la ville de Fortaleza, Brésil

2016-16 : FAUVET Pierre : Autorisation de mise sur le marché, défaillance de la responsabilité, et groupes de pression
\end{abstract}

La coordination scientifique des Cahiers du GREThA est assurée par Emmanuel PETIT. La mise en page est assurée par Julie VISSAGUET 